\title{
Review Article \\ Safety of Natural Insecticides: Toxic Effects on Experimental Animals
}

\author{
Abdel-Tawab H. Mossa $\mathbb{D}^{\mathbb{D}},{ }^{1}$ Samia M. M. Mohafrash ${ }^{\mathbb{D}},{ }^{1}$ and Natarajan Chandrasekaran $\mathbb{D}^{2}$ \\ ${ }^{1}$ Pesticide Chemistry Department, National Research Centre (NRC), 33 El Bohouth Street (Former El Tahrir St.), P.O. Box 12622, \\ Dokki, Giza, Egypt \\ ${ }^{2}$ Centre for Nanobiotechnology, Vellore Institute of Technology, Vellore, Tamil Nadu 632014, India
}

Correspondence should be addressed to Abdel-Tawab H. Mossa; abdeltawab.mossa@yahoo.com

Received 27 April 2018; Accepted 17 September 2018; Published 16 October 2018

Academic Editor: Hartmut Jaeschke

Copyright (C) 2018 Abdel-Tawab H. Mossa et al. This is an open access article distributed under the Creative Commons Attribution License, which permits unrestricted use, distribution, and reproduction in any medium, provided the original work is properly cited.

Long-term application and extensive use of synthetic insecticides have resulted in accumulating their residues in food, milk, water, and soil and cause adverse health effects to human and ecosystems. Therefore, application of natural insecticides in agriculture and public health sectors has been increased as alternative to synthetic insecticides. The question here is, are all natural insecticides safe. Therefore, the review presented here focuses on the safety of natural insecticides. Natural insecticides contain chemical, mineral, and biological materials and some products are available commercially, e.g., pyrethrum, neem, spinosad, rotenone, abamectin, Bacillus thuringiensis $(B t)$, garlic, cinnamon, pepper, and essential oil products. It can induce hepatotoxicity, renal toxicity, hematotoxicity, reproductive toxicity, neurotoxicity, and oxidative stress. It can induce mutagenicity, genotoxicity, and carcinogenicity in mammals. Some natural insecticides and active compounds from essential oils are classified in categories Ib (Highly hazardous) to U (unlikely toxic). Therefore, the selectivity and safety of natural insecticides not absolute and some natural compounds are toxic and induce adverse effects to experimental animals. In concussion, all natural insecticides are not safe and the term "natural" does not mean that compounds are safe. In this respect, the term "natural" is not synonymous with "organic" and not all-natural insecticide products are acceptable in organic farmers.

\section{Introduction}

Pesticides are playing important role in agriculture and public health. They make an important role by increasing the production of food and fiber and improving human health by reducing the rate of vector-borne diseases [1]. In addition to crop damage induced by pests, these pests that cause adverse effects on human health and domestic animals produce the toxic metabolites. In this respect, according to The Pesticide Manual about 812 active ingredients "pesticides" were registered until year 2000 [2]. Today's more than 10,400 pesticides are approved worldwide [3]. It has been reported that the consumption of pesticides accounts two million tons every year worldwide [4]. However, the word "pesticides" represented numerous type of pesticides (e.g., insecticides, herbicides, bactericides, nematicides, acaricides, fungicides, molluscicides, and rodenticides); each is active against specific pests (e.g., insect, weed, bacteria, nematode, fungi, snail, and rat).

Insecticides contain two types; the first is synthetic insecticides assigned to groups based on the mode of toxic action, such as groups of organochlorines, organophosphates, carbamates, and pyrethroids insecticides; the second is natural insecticides such as azadirachtin, rotenone, spinosad, and abamectin. The extensive and long-term application of synthetic insecticides has resulted in accumulating their residues in food, milk, water, soil, and other environmental components. It cause adverse health effects to human and ecosystems. Previous studies showed that synthetic insecticides such as malathion, methomyl, chlorpyrifos, pirimiphosmethyl, dimethoate, and $\beta$-cyfluthrin caused oxidative stress and liver and kidney damage in experimental animals [5-10]. It caused biochemical and hormonal alteration in sprayers 
TABLE 1: Acute toxicity hazard categories of pesticides and distribution of pesticides registered in Egypt in each categories [20].

\begin{tabular}{lccc}
\hline Category or class & \multicolumn{2}{c}{ Acute $\mathrm{LD}_{50} \mathrm{mg} / \mathrm{kg}$ body weight of the rat } & Classification by hazardous \\
& Oral & Dermal & Extremely \\
Ia & $<5$ & $<50$ & Highly \\
Ib & $5-50$ & $50-200$ & Moderately \\
II & $50-2000$ & $200-2000$ & Slightly \\
III & Over 2000 & 5000 or higher 2000 & Unlikely \\
U & & & \\
\hline
\end{tabular}

$$
\begin{aligned}
& \mathrm{R}=-\mathrm{CH}_{3} \text { (chrysanthemates) or }-\mathrm{CO}_{2} \mathrm{CH}_{3} \text { (pyrethrates) } \\
& \mathrm{R}_{\mathbf{1}}=-\mathrm{CH}=\mathrm{CH}_{2} \text { (pyrethrins) or }-\mathrm{CH}_{3} \text { (cinerin) or }-\mathrm{CH}_{\mathbf{2}} \mathrm{CH}_{3} \text { (jasmolin) }
\end{aligned}
$$

FIGURE 1: Chemical structure of pyrethrins (pyrethrum).

of cotton fields [11] and occupational exposure to pesticides accounts $4 \%$ of all human cancers [12].

Natural insecticides contain chemical, mineral, and biological materials and some products are available commercially, e.g., pyrethrum, neem, spinosad, rotenone, abamectin, Bacillus thuringiensis (Bt), garlic, cinnamon, pepper, and essential oil products [13-19]. Practically, the major categories of natural insecticides are botanical, soaps and oils, minerals, and microbial. The selectivity and safety of natural insecticides are not absolute and some natural compounds are toxic; for example, arsenic and nicotine are used historically as natural pesticides. Currently, these natural compounds are not considered as safe and not used as pesticides.

Therefore, the review presented here focuses on the safety of natural insecticides on experimental animals. Scientific databases were used to search for articles in this review.

\section{Acute Toxicity Hazard Categories of Pesticides}

According to the World Health Organization [20], pesticides were classified by hazard into five classes (Ia, Ib, II, III, and $U$ ) based on acute oral or dermal $\mathrm{LD}_{50} \mathrm{mg} / \mathrm{kg}$. body weight (b.wt.) for the rat (Table 1). Class Ia is classified as extremely hazardous which content pesticides with acute oral $\mathrm{LD}_{50}$ less than $5 \mathrm{mg} / \mathrm{kg}$. body weight $(<5)$ and dermal $\mathrm{LD}_{50}$ less than $50 \mathrm{mg} / \mathrm{kg}$. body weight $(<50)$. Pesticides in other categories, Ib (Highly hazardous), II (Moderately hazardous), and III (Slightly hazardous), have acute oral toxicity 5-50, 50-2000, and over $2000 \mathrm{mg} / \mathrm{kg}$. b.wt. and acute dermal toxicity 50-200, 200-2000, and over $2000 \mathrm{mg} / \mathrm{kg}$. b.wt., respectively. In contrast, category $U$ is classified as pesticides which are unlikely to present acute hazard and have acute oral or dermal toxicity $5000 \mathrm{mg} / \mathrm{kg}$. b.wt. or higher.

\section{Mechanism of Action of Some Common Natural Insecticides}

Several authors reported the mechanism of toxic action of different natural insecticides. The correlation between chemical structure and toxicity also was studied. In this part, the mechanisms of action of natural insecticides (pyrethrins, azadirachtin, spinosad, abamectin, mineral oils, Bacillus thuringiensis, Lecanicillium muscarium, and phosphine gas) will be discussed.

3.1. Pyrethrins (Pyrethrum). Pyrethrins (pyrethrum) are a mixture of natural chemical compounds found in the extract of chrysanthemum flowers [Tanacetum (= Chrysanthemum = Pyrethrum) cinerariaefolium]. Pyrethrum extract has six different compounds with insecticidal activity (Figure 1). These active compounds in the chrysanthemum flower extract are named pyrethrins [21]. Moreover, pyrethrins are registered as pesticides and more than 2000 commercial products are found worldwide [22]. Pyrethrins like other pyrethroids insecticides are neurotoxicant [23]. It modifies the function of voltage-gated sodium channels [24]. Pyrethrins can cause repetitive nerve impulses by alteration the permeability of excited nerve cells to the sodium ion [23, 25]. It causes other neurobiological effects on gamma amino butyric acid (GABA), noradrenergic, dopaminergic, and cholinergic neurotransmission [26].

According to The Pesticide Manual [27], the acute oral toxicity of pyrethrins $\mathrm{LD}_{50}$ is 2370 and $1030 \mathrm{mg} / \mathrm{kg}$ for male and female rats and $273-796 \mathrm{mg} / \mathrm{kg}$ for mice. However, according to the WHO recommended classification of pesticides [20], the active ingredient of pyrethrins insecticide is classified in class II as moderately hazardous.

3.2. Azadirachtin. Azadirachtin is the principal natural insecticidal ingredient isolated from neem seed extracts of the 


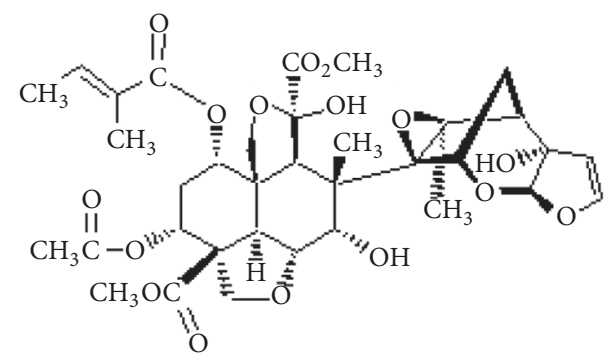

FIGURE 2: Chemical structure of azadirachtin.

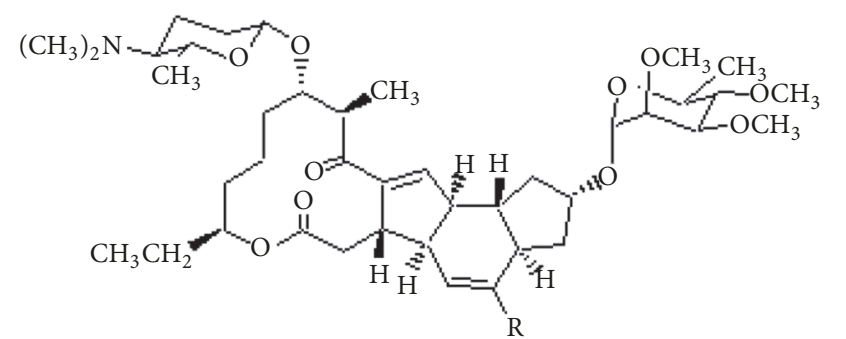

Spinosy A, $\mathrm{R}=\mathrm{H}-$

Spinosyn $\mathrm{D}, \mathrm{R}=\mathrm{CH}_{3^{-}}$

Figure 3: Chemical structure of spinosad.

neem tree (Azadirachta indica A. Juss) [28]. It causes growth disruption, antifeedant, and toxicity to insects [29]. This effect is due to the presence of a complex tetranortriterpenoid limonoid as a major compound (Figure 2). Another variety of limonoids is found in these extracts, e.g., salannin, nimbin, and nimbolide. According to The Pesticide Manual [27], the emulsion of neem is prepared from extracts containing azadirachtin (25\%) and other limonoids $(30-50 \%) \mathrm{w} / \mathrm{w}$ as active compounds. According to Mordue and Blackwell [30], the mechanism of insecticidal action "mode of action" of azadirachtin is due to (i) antifeedancy as result of effect of azadirachtin on deterrent and chemoreceptors (chemosensor); (ii) effect on juvenile and ecdysteroid hormone; (iii) direct effects on most insect tissues. The acute oral toxicity of azadirachtin $\mathrm{LD}_{50}$ for rats is more than $5000(>5000) \mathrm{mg} / \mathrm{kg}$ and formulation is classified in class IV according to EPA [27].

3.3. Spinosad. Spinosad is a natural and active insecticide produced by a soil actinomycete bacterium, Saccharopolyspora spinosa [31]. Spinosad contains a number of metabolites that have been named spinosyns (Figure 3). Spinosyns are a mixture of two active compounds spinosyn A and spinosyn D obtained from S. spinosa fermentation $[32,33]$.

Due to the low toxicity and safety to beneficial organisms, spinosad is considered as selective insecticides. Spinosad is a neurotoxin with novel mechanism of action by activation of the nicotinic acetylcholine receptor and gamma amino butyric acid (GABA) receptor [16] but at a different site of action from imidacloprid and nicotine. It is toxic active by ingestion or stomach action and contact. The acute oral toxicity $\left(\mathrm{LD}_{50}\right)$ for male is 3783 and $>5000 \mathrm{mg} / \mathrm{kg}$ for female rats [27].

3.4. Abamectin. Abamectin (ABA) is a natural insecticide with stomach action and contact. It has been produced by fermentation of Streptomyces avermitilis. The commercial product of abamectin contains two active compounds $\geq 80 \%$ avermectin Bla and $\leq 20 \%$ avermectin Blb (Figure 4). ABA is a neurotoxin with the specific mechanism of action [34]. It is effected in the nervous system by blocking the ion tropic $\alpha$ amino butyric acid (GABA) [35]. Abamectin has insecticidal, acaricidal, and nematocidal activity. The acute oral $\mathrm{LD}_{50}$ of abamectin is $10 \mathrm{mg} / \mathrm{kg}$ for rats in sesame oil and $221 \mathrm{mg} / \mathrm{kg}$ in water. $\mathrm{LD}_{50}$ for mice is $13.6 \mathrm{mg} / \mathrm{kg}$ in water [27]. According to WHO [20], it is classified in class II as moderately hazardous.

3.5. Mineral Oils. Mineral oils also called petroleum oils, paraffin oils, spray oils, white oils (refined grades), and adjuvant oils. Mineral oils contain mostly saturated and unsaturated aliphatic hydrocarbons. The mineral oils used as insecticides generally distill at temperature above $310^{\circ} \mathrm{C}$. These oils are produced by distillation and modification of crude mineral oils. Mineral oils are classified by the proportion distilling at $335^{\circ} \mathrm{C}$ to light (67-79\%), medium (40$49 \%)$, and heavy (10-25\%). Moreover, adjuvant oils are highly developed self-emulsifying oils, which produce a quickbreaking emulsion, spread rapidly, and support penetration of the active ingredient into the plant and pest.

The mode of toxic action of mineral oils is different from synthetic insecticides, which depend on physical and chemical properties of mineral oils. Moreover, physiological, anatomical, and behavioral characters of insect are playing essential role of mineral oil toxicity. According to Smith [36], the mechanism of toxic action of mineral oils when applied to eggs and used as ovicidal is due to (i) stopping the normal exchange of gases; (ii) stopping hatching due to change the water balance of the egg; (iii) dissolving the outer covering of the egg; (iv) penetrating the egg causing coagulation of the protoplasm; (v) interfering with enzyme or hormone activity. In contrast, when mineral oils are applied as insecticides, they cause toxic action by changes in insect tissue structure as a result to the fumigant effect of volatile compounds [37].

3.6. Bacillus thuringiensis (Bt). Bt is a special bacterium which can produce a number of active chemical compounds that are used commercially as insecticides to control insects in agriculture and public health sectors. The widespread use of $B t$ is mainly due to safety for humans and is environmentally friendly biopesticide worldwide; $B t$ cause mechanism of toxic action by insecticidal activity as stomach action. After application of $B t$ and ingestion by insect, the crystals of endotoxin are solubilized and cause damage in the epithelial cells of the gut. As a result, insects stop feeding and finally starve to death $[38,39]$.

3.7. Lecanicillium muscarium. The fungal pathogen. L. muscarium is grown naturally in soils. It is active against a widerange of insects in different species. It is a good and common 


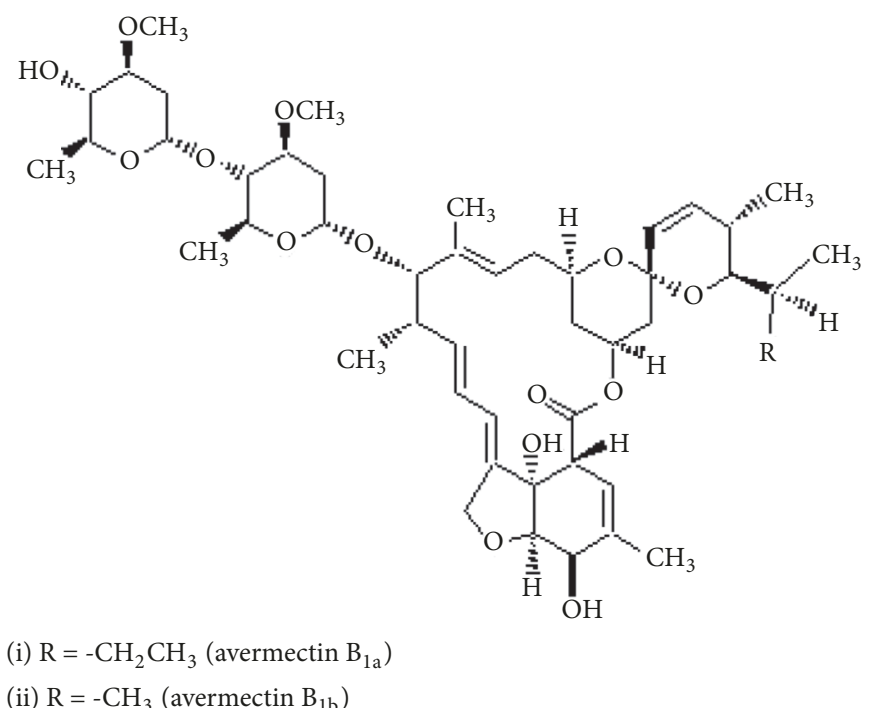

FIGURE 4: Chemical structure of abamectin.

pathogen infecting insect hosts worldwide under different geographical and climatic sites. L. muscarium commercial product has been in the market since 1980 [40]. It is active against whiteflies on different crops [41]. It was isolated from whiteflies, aphid, and other insect hosts. Previous studies stated that L. muscarium are reported as pathogens against different insects worldwide [42-44]. It has been reported that pathogenicity of Lecanicillium muscarium is caused by contacting the spores to the insect, germination on insect cuticle, penetration, and inside colonization culminating in host death [45].

3.8. Phosphine. Aluminum phosphide and magnesium phosphide were used as a source of phosphine gas for fumigation. The phosphine gas is active against a wide-ranging of insects.

Phosphine has an effect on respiratory, metabolic, and nervous system. It causes nerve poison. The acute oral toxicity $\left(\mathrm{LD}_{50}\right)$ for rats of aluminum phosphide is $8.7 \mathrm{mg} / \mathrm{kg}$ and for magnesium, phosphide is $11.2 \mathrm{mg} / \mathrm{kg}$ [27]. Due to high toxic effect of aluminum and magnesium phosphide on human, they restricted use of these chemicals.

\section{Toxicity of Some Essential Oil Compounds to Mammals}

Essential oils (EOs) are obtained from different part of plants by hydrodistillation and other methods. Plants in Lamiaceae family were reported as the high botanical sources. EOs are found generally in plants as mixtures of various active components especially monoterpenes (phenols and sesquiterpenes). However, several active compounds were isolated as major compounds from many plants such as 1,8-cineole (rosemary and eucalyptus), eugenol (clove oil), thymol (garden thyme), menthol (mint), asarones (calamus), carvacrol, and linalool (many plant species). Some EOs were used for protection of stored products and some have fumigant and contact insecticidal activities [46-48].

Some of these active compounds have toxic effect to mammals for example; the acute lethal dose $\left(\mathrm{LD}_{50}\right)$ of Thujone is $87.5 \mathrm{mg} / \mathrm{kg}$. b.wt. to mice through subcutaneous route and $500 \mathrm{mg} / \mathrm{kg}$. b.wt of Apiol to dogs through intravenous route. However, Table 2 shows the acute lethal dose of some active compounds $[47,49,50]$ and classification according to the WHO acute toxicity hazard categories [20]. Some of these active compounds have toxic effects to experimental animals and have been found in categories II and III.

\section{Adverse Effects of Natural Insecticides on Experimental Animals}

Several scientist studied the adverse toxic effect of natural insecticides on experimental animals. These effects include hepatotoxicity, hematotoxicity, renal toxicity, genotoxicity, and carcinogenicity. The effect on animals at critical period such as pregnancy, lactation, and weanling also was studied. The following is a summary of the studies conducted on some natural insecticides.

5.1. Body Weight and Relative Organs Weights. Body weight, weight gains, and organ weights are good criteria for studying the toxicity of xenobiotic in mammal's body and organs. The abnormal changes are used as an indicator of organ dysfunction, detoxification process, and toxicity (Table 3 ). According to USEPA [51], pyrethrins are slightly toxic to small mammals with an $\mathrm{LD}_{50} 700 \mathrm{mg} / \mathrm{kg}$. b.wt. It causes a reduction in body weight gain in pups during lactation period and the lowest-observed-adverse-effect level (LOAEL) is 65 $\mathrm{mg} / \mathrm{kg} /$ day based on decreased body weight. Springfield et al. [52] reported that oral administration of pyrethrum at $200 \mathrm{mg} / \mathrm{kg}$ for 23 days to male rats increased body and liver weights with decrease in hepatic DNA concentrations. Other 
TABLE 2: Toxicity of some essential oil compounds to experimental animals.

\begin{tabular}{|c|c|c|c|c|}
\hline Compound & Animal & Route & $\mathrm{LD}_{50} \mathrm{mg} / \mathrm{kg}$. b.wt. & WHO category \\
\hline \multicolumn{5}{|c|}{ Category II (Moderately hazardous), $50-2000 \mathrm{mg} / \mathrm{kg}$} \\
\hline Thujone & Mice & Subcutaneous & 87.5 & II \\
\hline Pulegone & Mice & Intraperitoneal & 150 & II \\
\hline 3-Isothujone & Mice & Subcutaneous & 442.2 & II \\
\hline Apiol & Dogs & Intravenous & 500 & II \\
\hline 2-Acetonaphthone & Mice & Oral & 599 & II \\
\hline 2-Methoxyphenol & Rats & Oral & 725 & II \\
\hline Thymol & Rats & Oral & 980 & II \\
\hline Linalool & Rats & Oral & $>1000$ & II \\
\hline Cinnamaldehyde & Guinea pigs & Oral & 1160 & II \\
\hline Methyl eugenol & Rats & Oral & 1179 & II \\
\hline Dillapiol & Rats & Oral & $1000-1500$ & II \\
\hline Anisaldehyde & Rats & Oral & 1510 & II \\
\hline$(+)$ Carvone & Rats & Oral & 1640 & II \\
\hline$\gamma$-terpinene & Rats & Oral & 1680 & II \\
\hline Thymol & Mice & Oral & 1800 & II \\
\hline Methyl chavicol & Rats & Oral & 1820 & II \\
\hline \multicolumn{5}{|c|}{ Category III (Slightly hazardous), over $2000 \mathrm{mg} / \mathrm{kg}$} \\
\hline trans-Anethole & Rats & Oral & 2090 & III \\
\hline Cinnamaldehyde & Rats & Oral & 2220 & III \\
\hline Maltol & Rats & Oral & 2330 & III \\
\hline 1,8-Cineole & Rats & Oral & 2480 & III \\
\hline Eugenol & Rats & Oral & 2680 & III \\
\hline Menthol & Rats & Oral & 3180 & III \\
\hline Terpinen-4-ol & Rats & Oral & 4300 & III \\
\hline d-Limonene & Rats & Oral & 4600 & III \\
\hline Citral & Rats & Oral & 4960 & III \\
\hline \multicolumn{5}{|c|}{ Category U (unlikely to present acute hazard), $5000 \mathrm{mg} / \mathrm{kg}$} \\
\hline Myrcene & Rats & Oral & 5000 & $\mathrm{U}$ \\
\hline
\end{tabular}

TABLE 3: Effect of exposure to some natural insecticides on body and organs weight in experimental animals.

\begin{tabular}{|c|c|c|c|c|c|c|}
\hline Insecticide & Treatment & $\begin{array}{c}\text { Dose } \\
\mathrm{mg} / \mathrm{kg} \text {. b.wt. or } \\
\text { animal/day }\end{array}$ & $\begin{array}{l}\text { Duration } \\
\text { (days) }\end{array}$ & Test animal & Organ & Reference \\
\hline Pyrethrum & oral & 200 & 23 & $\operatorname{rat}\left(0^{-}\right)$ & body $\uparrow$, liver $\uparrow$, & {$[52]$} \\
\hline Abamectin & oral & 3.802 & 14 & mice $\left(\sigma^{-}\right)$ & body $\downarrow$, liver $\uparrow$, kidney $\uparrow$ & {$[57]$} \\
\hline Abamectin & oral & 22.10 & 21 & $\operatorname{rat}\left(q, \sigma^{-}\right)$ & body $\downarrow$, liver $\uparrow$, kidney $\uparrow$ & [60] \\
\hline Spinosad & oral & 350 & 28 & mice $(ð)$ & body $\downarrow$, kidney $\uparrow$, spleen, $\uparrow$ & {$[68]$} \\
\hline \multirow{2}{*}{ Spinosad } & \multirow{2}{*}{ oral } & $10,50,200$ & 21 & 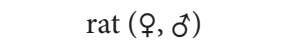 & body $\uparrow$ & \multirow{2}{*}{ [69] } \\
\hline & & $2.5,10,50$ & 28 & rabbits (ㅇ) & body $\uparrow$ & \\
\hline Bt & fed & 300,30 & 30 & rat $(\overbrace{}^{\star})$ & body, liver, kidney & {$[78]$} \\
\hline Phosphine & inhalation & $\begin{array}{l}3 \mathrm{~g} \text { of phostoxin } \\
\text { tablet ( } 1.5 \text { hrs/day) }\end{array}$ & 7 & $\operatorname{rat}\left(\delta^{\star}\right)$ & body $\uparrow$, kidney $\uparrow$ & {$[72]$} \\
\hline Phosphine & inhalation & $\begin{array}{c}0.5,1.5 \text { and } 4.5 \\
\mathrm{mg} / \mathrm{m} 3 \text { (6hrs/day) }\end{array}$ & $\begin{array}{c}13 \\
\text { (weeks) }\end{array}$ & 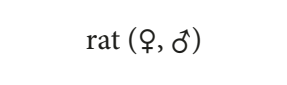 & body $\downarrow$ & {$[55]$} \\
\hline Azadirachtin & oral & $500,1000,1500$ & 90 & rat $(\phi, \overbrace{}^{\star})$ & $\begin{array}{l}\text { body, liver, kidney, testis, } \\
\text { spleen, heart, lung }\end{array}$ & {$[75]$} \\
\hline$B t$ & oral, dermal & $3,4,5 \mathrm{ml}$ & 1 & 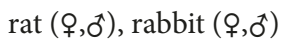 & body, liver, kidney & {$[77]$} \\
\hline Azadirachtin & fed & $5,25,50$ & 70 & 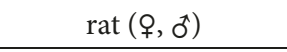 & body, liver, kidney, brain & {$[76]$} \\
\hline
\end{tabular}

Male (ð), female (९), increase “†”, decrease " $\downarrow$ ”, and no change "without symbol”. Bt: Bacillus thuringiensis. 
studies reported change in body and organ weights of mice [53], rats [54, 55], and dogs [56].

Significant decrease in body weight gain and increase in relative weight of liver and kidney was recorded in mice administrated abamectin at $1 / 10 \mathrm{LD}_{50}(3.802 \mathrm{mg} / \mathrm{kg}$. b.wt.) for 14 days [57]. The authors reported that the decrease in body weight might be due to the decrease in food consumption and or increase degradation of protein and lipids $[58,59]$. To study the effect of breastfeeding exposure to the ABA on body and organ weights of mothers and their officering, rat mothers were given ABA orally at doses of 22.10, 11.05, and $2.21 \mathrm{mg} / \mathrm{kg}$. b.wt from postnatal day 1 (PND1) until day 20 (PND20). High dose of ABA (22.10 mg/kg. b.wt.) induced high mortality in male and female suckling rats by $67.5 \%$ and $55.0 \%$, respectively [60]. Exposure to the ABA at dose of $22.10 \mathrm{mg} / \mathrm{kg}$. b.wt. induced signs of toxicity and increase in relative liver weight and body weights of mothers and their male and female pups. The authors reported that the decrease in body weight could be due to the neurotoxic action of ABA and their toxic metabolites. This neurotoxic effect leads to increase the degradation of protein and lipids [60-62]. Earlier studies reported decrease and increase in body weight, body weight gain, and relative organ weights of experimental animals exposed to insecticides $[63,64]$. Due to its high lipophilic nature, abamectin is accumulating at high concentration in animal tissues fat and milk of lactating dams and then transfer to offspring [60, 65]. Previous pharmacokinetic studies have been completed on ivermectin (a dihydro derivative of avermectin). These studies reported accumulation and transfer of ivermectin from mothers to their offspring. It was found in milk, liver, blood, and the high residues found in liver tissue [66]. Milk has the high concentration (3-4 times) of ivermectin compared to blood [67].

Oral administration of spinosad daily for 28 consecutive days to male mice at doses equal to $350 \mathrm{mg} / \mathrm{kg}$. b.wt induced significant decrease in body weight and increase in organ relative weight of kidney and spleen [68]. Breslin et al. [69] studied the effect of oral administration of spinosad at doses of 10,50 , and $200 \mathrm{mg} / \mathrm{kg}$. b.wt. to pregnant rats and doses of $2.5,10$, and $50 \mathrm{mg} / \mathrm{kg}$. b.wt. to pregnant New Zealand White rabbits during gestation period (21 day of rat and 28 days of rabbits). Spinosad at dose of $200 \mathrm{mg} / \mathrm{kg}$. b.wt. caused lower body weight of rat on gestation day 12 (GD12) and decreased body weight gain on GD 7-10. Spinosad at dose of $50 \mathrm{mg} / \mathrm{kg}$. b.wt. caused loss in body weight of rabbits at GD7-10 while the body weight gain decreased by $30 \%$ during the dosing period (GD7-20). Male and female rats are exposed to spinosad through feed in diet containing spinosad at concentration ranging from 0.003 to $0.4 \%$ for 13 weeks. It induced reduction in body weight and mortality in rats fed in diet contains $0.4 \%$ spinosad [70]. Spinosad at doses of $0.02,9$, and $37.38 \mathrm{mg} / \mathrm{kg}$. b.wt decrease body weight of treated rats [71].

Ibegbu et al. [72] found that body weight and relative kidney weight were significant increase in male rat exposed to aluminum phosphide at concentration $3 \mathrm{~g}$ of phostoxin tablet (1.5 hrs /day). Other studies showed the effect of phosphine on body weight of experimental animals at different concentrations. Newton et al. [55] studied the effect of phosphine gas on male and female rats. Rats were exposed to phosphine gas at levels $0.5,1.5$, and $4.5 \mathrm{mg} / \mathrm{m}^{3}$ for $6 \mathrm{hrs} /$ day above 13 weeks. Inhalation exposure to phosphine gas caused significant decrease in body weight, especially at a high level of exposure. Other studies also reported reduction in body weight gains in rat exposed to phosphine [73, 74].

90-day subchronic study of azadirachtin at doses of 500, 1000 , and $1500 \mathrm{mg} / \mathrm{kg} /$ day was completed in male and female rats [75]. There were no signs of toxicity, mortality, and changes in body and organ weights in male and female rats exposed to azadirachtin at all tested doses. Srivastava and Raizada [76] fed rats on diet contain azadirachtin at concentrations of 100,500, and $1000 \mathrm{ppm}(5,25$ and 50 $\mathrm{mg} / \mathrm{kg}$. b.wt.) for evaluation the toxicity during postnatal development for two generations. There was no toxicological effect of azadirachtin in body weight, liver, kidney, and brain of pups over two generations. It has been reported that Bacillus thuringiensis (Bt) does not induce any changes in body and organ weights in rat and rabbits $[77,78]$.

5.2. Hepatotoxicity. Liver is an important organ in the human body that plays an essential role in metabolism and detoxification of xenobiotic such as insecticides. Previous studies showed that the progress of liver toxicity and injury could be done through the two-stage course [79]. This two-stage contains direct interaction between toxin and hepatic cell, initiation of the injury [80], and development of the injury in a toxin-independent (Table 4). The mechanism of toxic liver injury in second stage is complete through (i) inflammatory of hepatic cells [81], (ii) increase of oxidative stress and lipid peroxidation [82], and (iii) cell membrane damage and leakage of degrading enzymes [80].

Pyrethrins or pyrethrum can be found as the dust of ground flowers or liquid as the crud extract. It can be used for control insects in agriculture and public health sectors. When pyrethrins exposed to sunlight, it breaks down quickly in the environment. The activities of hepatic microsomal enzymes, e.g., EPN detoxification (ethyl p-nitrophenyl thionobenzenephosphonate) such as p-nitroanisole demethylation and hexobarbital oxidation in addition to cytochrome $\mathrm{P}_{450}$, were increased in male rat administrated pyrethrum oral at dose of $200 \mathrm{mg} / \mathrm{kg}$. b.wt. for 23 days [52]. The authors reported significant alteration hepatic pyrethrum metabolism and detoxification enzymes in the liver of male rats. It caused changes in liver enzymes and histopathological alterations in liver tissue in experimental animals such as mice, rats, rabbits, and dogs [53-56]. When rats were fed in feed, containing pyrethrins at $1000 \mathrm{mg} / \mathrm{kg}$. b.wt. (high dose), liver dysfunction and damage were recorded [83]. Pyrethrins and other synthetic pyrethroids are neurotoxic compounds and can induce hepatotoxicity and liver damage in experimental animals. They caused alteration in liver biomarkers such as AST, ALT, ALP, LDH, albumin, and total protein in rat $[10$, $84,85]$ and mice [86].

Abamectin (ABA) induced hepatotoxicity when administrated orally to male and female rats (Rattus norvegicus) at dose of $2.13 \mathrm{mg} / \mathrm{animal} / \mathrm{day}$ for 28 days [87]. After the treatment period, the animal was kept 14 days without 
TABLE 4: Effect of exposure to some natural insecticides on liver function biomarkers in experimental animals.

\begin{tabular}{|c|c|c|c|c|c|c|c|}
\hline Insecticide & Treatment & $\begin{array}{c}\text { Dose } \\
\mathrm{mg} / \mathrm{kg} \text {. b.wt. or } \\
\text { animal/day }\end{array}$ & $\begin{array}{c}\text { Duration } \\
\text { (days) }\end{array}$ & Test animal & Sample & Liver function biomarkers & Reference \\
\hline Abamectin & Oral & 2.13 & 28 & $\operatorname{rat}($ ㅇ, ô) & plasma, liver & $\mathrm{AST} \uparrow, \mathrm{ALT} \uparrow, \mathrm{ALP} \uparrow$, glucose $\uparrow$ & {$[87]$} \\
\hline Abamectin & Fed & $1.81,0.181$ & 30 & $\operatorname{rat}\left(\sigma^{*}\right)$ & serum & $\mathrm{AST} \uparrow, \mathrm{ALT} \uparrow, \mathrm{ACP} \uparrow, \mathrm{ALP} \uparrow, \mathrm{ALB} \downarrow, \mathrm{TP} \downarrow$ & {$[78]$} \\
\hline Bt & Fed & 300,30 & 30 & & & AST, ALT, ACP, ALP, ALB, TP & {$[1 / 8]$} \\
\hline Abamectin & Oral & 30,10 & 30,210 & $\operatorname{rat}\left(0^{\star}\right)$ & plasma & $\mathrm{AST} \uparrow, \mathrm{ALP} \uparrow, \mathrm{ALB} \uparrow, \mathrm{TP} \uparrow$ & [63] \\
\hline Abamectin & Oral & 3.802 & 14 & $\operatorname{mice}\left(\oslash^{\star}\right)$ & serum & $\mathrm{AST} \uparrow, \mathrm{ALT} \uparrow, \mathrm{ALP} \uparrow$ & [57] \\
\hline Spinosad & Oral & 35,350 & 28 & mice $\left(ઠ^{\star}\right)$ & serum & ALT $\uparrow, \mathrm{AST} \uparrow, \mathrm{ALB} \uparrow, \mathrm{TP}, \mathrm{TG}$ & [68] \\
\hline Pyrethrum & Oral & 200 & 23 & $\operatorname{rat}\left(0^{\star}\right)$ & liver & EPN, Cytochromes $\mathrm{P}_{450}$ & {$[52]$} \\
\hline Spinosad & Fed & $16 \mathrm{ppm}$ & 90 & $\operatorname{rat}\left(0^{\star}\right)$ & serum & $\mathrm{AST} \uparrow, \mathrm{ALP} \uparrow, \mathrm{ALT} \uparrow, \mathrm{ACP} \uparrow$ & [90] \\
\hline Spinosad & Oral & $0.02,9,37.38$ & 56 & rat $\left(ठ^{\Uparrow}\right)$ & serum & $\mathrm{AST} \uparrow, \mathrm{ALT} \uparrow, \mathrm{ALP} \uparrow$ & {$[91]$} \\
\hline $\mathrm{Bt}$ & Oral & $3,4,5 \mathrm{ml}$ & 1 & $\operatorname{rat}(\$, \overbrace{}^{*})$ & serum & ALT, TP, glucose & [77] \\
\hline $\mathrm{ALP}^{*}$ & Oral & 20 & 1 & rat $\left({ }^{\lambda}\right)$ & liver & $\mathrm{LDH} \uparrow$ & {$[97]$} \\
\hline
\end{tabular}

Male (ठ), female (), increase " $\uparrow$ ", decrease “ $\downarrow$ ", and no change "without symbol". ALP: alkaline phosphatase; ACP: acid phosphatase; ALB: albumin; and TP: total protein. TG: total triglycerides; EPN detoxification: ethyl p-nitrophenyl thionobenzenephosphonate such as p-nitroanisole demethylation and hexobarbital oxidation. Bt: Bacillus thuringiensis; ALP* : aluminum phosphide; LDH: lactate dehydrogenase.

treatments as withdrawal period. ABA induced significant increase in plasma glucose and liver dysfunction biomarkers such as aspartase aminotransferase (AST), alanine transaminase (ALT), and $\gamma$ glutamyl transpeptidase $(\gamma-\mathrm{Gt})$ in male and female rats. It caused histopathological alteration in liver tissue in male and female rats. The authors reported that the residue of $\mathrm{ABA}$ (B1a) was found in plasma samples after 14 and 28 days of treatment while no residues was detected after 42 days. In contrast, Bla residue in liver was detected after 42 days. The presence of Bla residue in the liver for a longer period (42 days) compared with plasma ( 28 days) is due to the elimination of Bla from plasma by the fecal route and inhibition of g P-glycoprotein (P-gp) which lead to increased accumulation of ABA in the liver [88]. Abamectin (Vertemic $1.8 \% \mathrm{EC})$ was administered to male rats at sublethal dose of $30 \mathrm{mg} / \mathrm{kg}$. b.wt. $\left(1 / 10 \mathrm{LD}_{50}\right)$ for 30 days (three doses per week) and at dose of $10 \mathrm{mg} / \mathrm{kg}$. b.wt. $\left(1 / 30 \mathrm{LD}_{50}\right)$ was administrated to another group for 210 days (one dose per week). ABA caused significant elevated liver enzymes in plasma (AST and ALT). It induced histopathological changes in liver tissue in a dose-dependent mater [63]. The toxic effect of ABA also was studied on female rats and their male and female pups during the lactation period [60]. ABA was administered orally to mothers at doses of $22.10,11.05$, and $2.21 \mathrm{mg} / \mathrm{kg}$. b.wt from postnatal days 1-20 (PND1-20). It induced significant alteration in serum liver biomarkers such as AST, ALT, AL, and lactate dehydrogenase $(\mathrm{LDH})$ in the mothers and their male and female pups in a dose-dependent manner. ElGendy et al. [57] studied the acute toxicity of abamectin at sublethal dose $(3.802 \mathrm{mg} / \mathrm{kg}$. b.wt.) in male mice for 14 days. Significant increase in AST, ALT, and ALP of mice exposed to ABA was found along with histopathological alteration in liver tissue. Eissa and Zidan [78] evaluated the toxicity of abamectin on the liver of male albino rats. ABA caused significant alteration liver function biomarkers such as AST, ALT, alkaline phosphatase (ALP), acid phosphatase $(\mathrm{ACP})$, albumin (ALB), and total protein (TP) in male rats administrated dietary doses of 1.81 and $0.181 \mathrm{mg} / \mathrm{kg}$.b.wt. $\left(1 / 10\right.$ and $\left.1 / 100 \mathrm{LD}_{50}\right)$ for 30 days. The authors showed that the increase in liver enzymes could be due to the change of cell membrane permeability because of liver and hepatocyte damage. Other studies showed that the ABA could change the function of hepatic cells and induce liver damage and hepatotoxicity. It caused an increase in liver enzyme such as serum AST of rat exposed to the ABA at dose of 1 and 20 $\mathrm{mg} / \mathrm{kg}$. b.wt. [89].

Oral administration of spinosad daily for 14 consecutive days at doses equal to 35 and $350 \mathrm{mg} / \mathrm{kg}$. b.wt caused liver damage in male mice. It induced significant elevation in liver function enzyme (AST and ALT) and in triglycerides [68]. Male and female rats are exposed to spinosad through feed in diet containing spinosad at concentration ranging from 0.003 to $0.4 \%$ for 13 weeks. It induced hepatotoxicity and liver damage in rats' feed in diet containing $0.4 \%$ spinosad [70]. Zidan [90] studied the effect of exposure to spinosad on male rats. Rats were fed on wheat grains treated with spinosad at concentration $16 \mathrm{ppm}$ for 90 consecutive days. At the end of the experimental period, biochemical parameters of the liver (AST, ALT, ALP, ACP, and albumin) were significant changes. Spinosad was evaluated for hepatotoxicity in male rats. Spinosad was orally administered for 8 weeks to male rats at doses of $0.02,9$, and $37.38 \mathrm{mg} / \mathrm{kg}$. b.wt corresponding to Acceptable Daily Intake (ADI), No Observed Adverse Effect Level (NOAEL), and $1 / 100 \mathrm{LD}_{50}$, respectively [91]. It caused significant alteration in liver function enzymes and histopathological alteration especially at high dose. In addition, it induced significant elevation in bilirubin (total and direct) in treated rats. Previous studies also reported hepatotoxicity of spinosad and alteration liver enzymes such as AST, ALT, and ALP on rats, rabbits, and Nile tilapia, Oreochromis niloticus $[69,92,93]$.

Eissa and Zidan [78] evaluated the toxicity of Bacillus thuringiensis on the liver of male albino rats. Bt showed insignificant changes in liver dysfunction biomarkers of rat 
TABLE 5: Effect of exposure to some natural insecticides on kidney function biomarkers in experimental animals.

\begin{tabular}{|c|c|c|c|c|c|c|c|}
\hline Insecticide & Treatment & $\begin{array}{c}\text { Dose } \\
\mathrm{mg} / \mathrm{kg} \text {. b.wt. or } \\
\text { animal/day }\end{array}$ & $\begin{array}{l}\text { Duration } \\
\text { (days) }\end{array}$ & Test animal & Sample & kidney function biomarkers & Reference \\
\hline Pyrethrum & Oral & 170 & 90 & rat $($ (ᄋ, ô) & kidney & --- & {$[98]$} \\
\hline Abamectin & Fed & $1.81,0.181$ & 30 & $\operatorname{rat}\left(0^{\top}\right)$ & serum & uric acid $\uparrow$, creatinine $\uparrow$ & [78] \\
\hline Abamectin & Oral & 3.802 & 14 & $\operatorname{mice}(\hat{0})$ & serum & urea $\uparrow$, creatinine $\uparrow$ & {$[57]$} \\
\hline Abamectin & Oral & $\begin{array}{c}2.21,11.05 \\
22.10\end{array}$ & 21 & 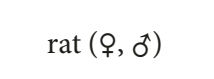 & serum & uric acid $\uparrow$, creatinine $\uparrow$ & {$[60]$} \\
\hline Azadirachtin & Oral & $500,1000,1500$ & 90 & $\operatorname{rat}(\overbrace{}^{\star})$ & serum & uric acid, creatinine & {$[75]$} \\
\hline Spinosad & Oral & 35,350 & 28 & $\operatorname{mice}\left(0^{\star}\right)$ & serum & urea & [68] \\
\hline Azadirachtin & Fed & $5,25,50$ & & $\operatorname{rat}(\phi, \overbrace{}^{\star})$ & serum & urea, creatinine & {$[76]$} \\
\hline Spinosad & Oral & $0.02,9,37.38$ & 8 weeks & $\operatorname{rat}(\overbrace{}^{\top})$ & serum & uric acid $\downarrow$ & [91] \\
\hline Bt (toxin) & Oral & $20 \mathrm{mg} / 100 \mathrm{~g}$ & 21 & rat $\left(\right.$ (, $\left.0^{\star}\right)$ & kidney & kidney & {$[94]$} \\
\hline Bt ( CrylIal2 toxin) & Diet & $0.1 \%$ & 10 & $\operatorname{rat}(\widehat{0})$ & kidney & urea nitrogen & {$[100]$} \\
\hline Phosphine & inhalation & $\begin{array}{c}1,5,10 \mathrm{ppm} ; \\
1.25,2.5,5 \mathrm{ppm}\end{array}$ & $\begin{array}{c}4 \\
14\end{array}$ & 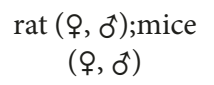 & serum & urine nitrogen $\uparrow$ & [101] \\
\hline Abamectin & Oral & $0.44,0.87$ & 4,8 weeks & rat $(\overbrace{}^{\star})$ & serum & urea $\uparrow$, uric acid $\uparrow$, creatinine $\uparrow$ & {$[99]$} \\
\hline
\end{tabular}

Male (ઠ), female (ㅇ), increase “ $\uparrow$ ”, decrease “ $\downarrow$ ”, no change "without symbol”, and Bacillus thuringiensis (Bt).

that has been administrated dietary doses of $300,30 \mathrm{mg} / \mathrm{kg}$. b.wt. (1/10 and $\left.1 / 100 \mathrm{LD}_{50}\right)$. Meher et al. [77] reported that wettable powder formulation of Bacillus thuringiensis var. kenyae (B.t.k.) is nontoxic to rats given one single oral dose of 3,4 , and $5 \mathrm{ml} \mathrm{Bt} \mathrm{suspension}\left(2.5 \times 10^{7}\right.$ spores $\left./ \mathrm{ml}\right)$ in acute toxicity study and toxicity was noted for 21 days. The authors found that acute oral $\mathrm{LD}_{50}$ in rats was higher than $5 \mathrm{ml}$ of Bt containing $\left(2.5 \times 10^{7}\right.$ spores $\left./ \mathrm{ml}\right)$ and $\mathrm{LC}_{50}$ in fish was higher than $1000 \mathrm{mg} / \mathrm{L}\left(2.5 \times 10^{7}\right.$ spores $\left./ \mathrm{ml}\right)$, respectively. In cases of rabbits, the acute dermal toxicity $\left(\mathrm{LD}_{50}\right)$ was higher than $2.5 \times 10^{7}$ spores $/ \mathrm{ml}$. Bt did not induce a significant alteration in the liver biomarkers, such as ALT, total protein, and glucose both in rats and in rabbits. In contrast, toxin of Bacillus thuringiensis (XenTari ${ }^{\circledR}$ ) when administrated to pregnant rats at $370 \mathrm{mg} / 100 \mathrm{~g}$ equal to a dose of $20 \mathrm{mg} / 100 \mathrm{~g}$ of the protoxin (Cry subspecies Aizawai) altered liver function parameters and induced liver damage [94]. Moreover, Bt (Dipel $\left.{ }^{\circledR}\right)$ can alter the defense behavior of hepatocytes and induce oxidative damage, lipid peroxidation, and damage of hepatocytes membrane in rats $[95,96]$.

Aluminum phosphide (ALP) is used as insecticides against many stored insects as fumigants. The inhalation toxicity of this compound is due to formation of phosphine gas because of contact of aluminum phosphide with moisture. ALP induced elevation in lactate dehydrogenase (LDH) in rats which received one single dose equal to $20 \mathrm{mg} / \mathrm{kg}$. b.wt. It caused alteration in liver antioxidant enzymes and histological alteration [97].

5.3. Renal Toxicity. Although the liver is considered the major target organ for toxic compounds and plays an essential role of metabolism and detoxification, the kidney is similar, an essential site of damage after exposure to toxic compounds and their toxic metabolites. The kidney is playing an essential role with multifunction of elimination waste from blood, balance fluids in the body, and other important functions. Natural insecticides caused adverse toxic effects on the kidney in experimental animals (Table 5). Rats received pyrethrins at dose of $170 \mathrm{mg} / \mathrm{kg}$. b.wt. for three moths showing degeneration in tubules and kidney damage [98].

Renal toxicity induced by abamectin was evaluated in male rats [78]. Rats were administered dietary ABA at doses of $1 / 10$ or $1 / 100 \mathrm{LD}_{50}$ for 30 repeated days. ABA induced significant changes in kidney biomarkers such as uric acid and creatinine concentration and histological alteration in kidney tissue. ABA induced significant increase in kidney markers such as urea and creatinine concentration and histological changes in male mice received dose equal to $1 / 10 \mathrm{LD}_{50}$ for 14 days [83]. It caused an increase in kidney dysfunction biomarkers in male and female pups whose mothers are exposed to ABA at doses of 22.10, 11.05, and $2.21 \mathrm{mg} / \mathrm{kg}$. b.wt during lactation period [60]. The authors reported also changes in kidney tissue structure, especially at high dose. ABA was orally administered to two groups of male rats at a dose equal to $0.44 \mathrm{mg} / \mathrm{kg}$. b.wt. $\left(1 / 20 \mathrm{LD}_{50}\right)$ and $0.87 \mathrm{mg} / \mathrm{kg}$. b.wt. $\left(1 / 10 \mathrm{LD}_{50}\right)$ for 4 weeks and 8 weeks, respectively. ABA induced significant increase in urea, uric acid, and creatinine concentrations in serum at 4 and 8 weeks in a dose-dependent manner. It caused histological changes in tissue structure and the effect increase with increasing exposure time [99].

Azadirachtin administered to male rat at doses of 500, 1000 , and $1500 \mathrm{mg} / \mathrm{kg}$. b.wt. for 90 days did not induce significant changes in kidney parameters or histological structure [75]. Srivastava and Raizada [76] evaluated the toxic effect of azadirachtin during postnatal development of rats. Rats were fed on diet containing azadirachtin at concentrations 100, 500, and $1000 \mathrm{ppm}$ (5, 25, and $50 \mathrm{mg} / \mathrm{kg}$. b.wt). No adverse effects were recorded in rats over two generations with no effect on kidney function or tissue. The adverse toxic effect 
of spinosad at dose 35 and $350 \mathrm{mg} / \mathrm{kg}$ on some biochemical and histological parameters of kidney of male mice was evaluated. Significant increase in urea concentration in serum of male mice received $350 \mathrm{mg} / \mathrm{kg}$ spinosad. Histopathological investigation revealed cytoplasmic degeneration and cell necrosis in kidney [68]. Spinosad in two studies conducted on male and female mice fed in feed containing 0.005, 0.015, 0.045 , and $0.12 \%$ and $0.0025,0.008$, or $0.036 \%$ spinosad, respectively, for 13 -week and 18 -month chronic studies. The histopathological alteration in mouse kidney was noted at doses more than $0.015 \%$ [92]. Spinosad was administrated to male rat at doses equal to ADI, NOAEL, and $1 / 100 \mathrm{LD}_{50}(0.02$, 9.0 , and $37.38 \mathrm{mg} / \mathrm{kg}$. b.wt.) for 8 weeks via the oral route. Spinosad at high two doses ( 9 and $37.38 \mathrm{mg} / \mathrm{kg}$. b.wt.) induced significant changes in uric acid concentration of male rats and histopathological alteration such as degeneration, necrosis [91].

Lemos et al. [94] reported that Bacillus thuringiensis toxin (XenTari ${ }^{\circledR}$ ) induces necrosis, degeneration in tubules and proliferative glomerulonephritis in kidney of pregnant rats received $370 \mathrm{mg} / 100 \mathrm{~g}$ equal to a dose of $20 \mathrm{mg} / 100 \mathrm{~g}$ of the protoxin (Cry subspecies Aizawai). The authors explained the alteration in the kidney after exposure to $B t$ toxins is due to the effect of toxins on the immune system through the proliferation of mesangial cells and their infiltration in the kidney tissue. The CrylIa12 entomotoxin from a Brazilian Bt. strain was used to evaluate the adverse effects of diet Crylla12 protein for 10 days to rats on blood urea nitrogen and kidney [100]. The authors found no significant changes in blood urea nitrogen and no histopathological alteration in kidney tissue of the rats diet with $0.1 \%$ of the Crylla12 toxin for 10 days.

Morgan et al. [101] evaluated the inhalation toxicity of phosphine (PH3) on males and females rats and mice. Male and female mice and rats were exposed to concentration 1,5,10 ppm and males and females were exposed to $1.25,2.5$, and 5 ppm for 4 days and 14 days, respectively. Phosphine at high concentration $(10 \mathrm{ppm})$ caused an increase in concentration of urine nitrogen in males and females rats and mice. It caused histopathological alteration in kidney such as degeneration and necrosis of renal tubule epithelium. The authors explained that the increase in urine nitrogen could be due to the toxic effect of phosphine in kidney that decreased renal blood flow and may be due to the kidney dehydration.

It has been confirmed that Lecanicillium muscarium strain Ve6 is not a plant and human pathogens. As shown in the literature, Lecanicillium muscarium (Lecanicillium spp) was previously widely known as Verticillium lecanii (Verticillium spp.). To the best of our knowledge, there are no signs of toxicity or mortality and no fungi were detected in organs of rats and mice treated with the level ranged from $6.9 \times 10^{6}$ to $3.0 \times 10^{8}$ spores/animal [102].

5.4. Hematotoxicity. The toxic effect of insecticides on hematological parameters is extensively used to study the effect on blood components. Insecticide can induce hematotoxicity in experimental animals and changes in hemoglobin $(\mathrm{Hb})$ concentration, red blood cells count (RBCs), white blood cells count (WBCs), mean corpuscular volume (MCV), and mean corpuscular hemoglobin $(\mathrm{MCH})$ and other components. Abamectin was administered to male rats at dose equal to $1 / 10$ and $1 / 100 \mathrm{LD}_{50}$ daily for 30 days. Some hematological parameters in blood were decreased such as $\mathrm{Hb}, \mathrm{RBCs}$ and WBCs [78]. The acute toxicity of ABA was investigated in male mice [57].

Mice was exposed to $\mathrm{ABA}$ at dose equal to $1 / 10 \mathrm{LD}_{50}$ for 14 days. ABA induced significant changes in hematological parameters in the blood of treated mice. It caused significant reduction in $\mathrm{Hb}$ concentration, packed cell volume (PCV) and RBCs and increase in WBCs, MCV, and MCH. Mansour et al. [91] evaluated the hematotoxicity of spinosad as single and repeated dose for 21 days on male rats. Rats were administrated spinosad at doses of 0.02 (ADI), 9 (NOAEL), and $37.38 \mathrm{mg} / \mathrm{kg}$. b.wt. $\left(1 / 100 \mathrm{LD}_{50}\right)$. Spinosad induced decrease in $\mathrm{RBC}$ and $\mathrm{Hb}$ while it induced increase in WBCs, lymphocyte concentration, and granulocyte concentration. Other studies reported hematotoxicity of spinosad to experimental animals; for example, it increases WBCs in female rats after 18 months of exposure [70]. It increases WBCs in female rats after receiving $0.036 \%$ and 0.024 for 12 months [92].

Biosafety studies have confirmed that exposures to $B t$ spore-crystals induce minor toxic effects to mammals. It has been reported that product of $\mathrm{Bt}$ is noninfectious and they are toxic to mammals at doses above $10^{8}$ and $10^{11}$ colony forming units (CFU) per mouse and per human, respectively [103]. Male and female mice were orally exposed $72 \mathrm{~h}$ to $B t$ Crylla and CrylBa6. Bt caused significant decrease in $\mathrm{MCH}$ whereas insignificant changes were noted in RBCs, Hb, and HCT [104]. Significant reduction was found in MCV after treatment by Cry10Aa $\left(5 \times 10^{9}\right.$ spores $\left./ \mathrm{kg}\right)$, Cry10Aa $\left(1 \times 10^{10}\right.$ spores/kg), and CrylBa6. Other studies reported hematotoxicity of natural insecticides such as abamectin, spinosad, azadirachtin, pyrethrins, and phosphine on experimental animals [78, 101, 105-107].

5.5. Reproductive Toxicity. Several researchers reported reproductive toxicity of natural insecticides on experimental animals. Abamectin was administered to male rats orally at dose of $10 \mathrm{mg} / \mathrm{kg}$. b.wt. for six weeks [108]. It induced alteration in testis function and histological alterations. The results of reproductive toxicity induced by pyrethrins are different depending on animal species. Normal litters were obtained from pregnant rabbits who fed on diet containing pyrethrin up to $90 \mathrm{mg} / \mathrm{kg}$ during the superficial period of pregnancy. No mortality was recorded in rabbit litters at birth after exposing to pyrethrins. When rats fed on a diet containing pyrethrins at $5000 \mathrm{mg} / \mathrm{kg}$ for 21 days before their initial mating, reduction in the weight of birth litter was recorded [109]. Normal litters also were recorded in rabbits fed at moderate dose of pyrethrins around $90 \mathrm{mg} / \mathrm{kg}$. b.wt. during pregnancy, while reduction in pup weights at birth was noted in mothers fed to pyrethrins at dose of $500 \mathrm{mg} / \mathrm{kg}$. b.wt. (high doses) for 21 days before their first mating [83]. In rabbits exposed to pyrethrins, there are no birth defects [110].

ABA caused an increase in the concentration of testosterone in plasma of male rats and decrease in sperm count 
TABLE 6: Oxidative stress induced by some natural insecticides in experimental animals.

\begin{tabular}{|c|c|c|c|c|c|c|c|}
\hline Insecticide & Treatment & $\begin{array}{c}\text { Dose } \\
\mathrm{mg} / \mathrm{kg} \text {. b.wt. or } \\
\text { animal/day }\end{array}$ & $\begin{array}{l}\text { Duration } \\
\text { (days) }\end{array}$ & Test animal & Sample & Oxidative stress biomarkers & Reference \\
\hline Spinosad & Oral & 347.49 & 28 & $\operatorname{rat}\left(0^{\star}\right)$ & liver & $\mathrm{SOD} \downarrow, \mathrm{CAT} \downarrow, \mathrm{GST} \downarrow, \mathrm{GPx} \uparrow, \mathrm{GSH} \downarrow, \mathrm{LPO} \uparrow$ & {$[120]$} \\
\hline Spinosad & dipping & $25,50,75 \mathrm{mg} / \mathrm{L}$ & $\begin{array}{c}24,48,72 \\
\text { h. }\end{array}$ & fish & liver & GST $\uparrow, \mathrm{GPx} \uparrow, \mathrm{GSH} \downarrow, \mathrm{LPO} \uparrow$ & [93] \\
\hline Abamectin & Oral & $\begin{array}{l}2.21,11.05 \\
22.10\end{array}$ & 21 & $\operatorname{rat}\left(\%, o^{-}\right)$ & $\begin{array}{l}\text { liver, } \\
\text { kidney }\end{array}$ & SOD $\uparrow$, GST $\uparrow, \mathrm{LPO} \downarrow$ & {$[60]$} \\
\hline Abamectin & Oral & 30 & 30 & $\operatorname{rat}\left({ }^{\star}\right)$ & $\begin{array}{l}\text { kidney, } \\
\text { brain }\end{array}$ & SOD $\downarrow, \mathrm{CAT} \downarrow, \mathrm{GST} \downarrow, \mathrm{GSH} \downarrow, \mathrm{LPO} \uparrow$ & {$[121]$} \\
\hline Abamectin & Oral & 1,4 & 7,28 & $\operatorname{rat}(\widehat{0})$ & testis & 4-HNE $\downarrow, \mathrm{PAR} \downarrow, \downarrow$ PARP $\downarrow$ & [113] \\
\hline Abamectin & Fed & $20,40,60$ & $30,60,90$ & pigeon & spleen & $\mathrm{SOD} \downarrow, \mathrm{GPx} \downarrow, \mathrm{T}-\mathrm{AOC} \downarrow, \mathrm{LPO} \uparrow$ & {$[122]$} \\
\hline $\begin{array}{l}\text { Bt toxin } \\
\text { "Vip3Aa16" }\end{array}$ & Oral & $\begin{array}{c}2500,5000 \\
7500\end{array}$ & 14 & mice & $\begin{array}{l}\text { liver, } \\
\text { kidney }\end{array}$ & $\mathrm{SOD}, \mathrm{LPO}, \mathrm{H}_{2} \mathrm{O}_{2}$ & [123] \\
\hline Abamectin & Oral & 3.3 & $4,24,48 \mathrm{~h}$. & rat & brain & $\mathrm{SOD} \downarrow, \mathrm{GSH} \downarrow, \mathrm{LPO} \uparrow$ & {$[64]$} \\
\hline Phosphine & i.p. & 4 & $30 \mathrm{~min}$ & rat & $\begin{array}{l}\text { kidney, } \\
\text { heart }\end{array}$ & SOD $\downarrow, \mathrm{CAT} \downarrow, \mathrm{GPx} \downarrow$, GSH $\downarrow, \mathrm{LPO} \uparrow$ & {$[124]$} \\
\hline Phosphine & i.p. & 2 & $30 \mathrm{~min}$ & rat & $\begin{array}{l}\text { brain, } \\
\text { liver, lung }\end{array}$ & $\mathrm{GSH} \downarrow, \mathrm{LPO} \uparrow$ & [125] \\
\hline
\end{tabular}

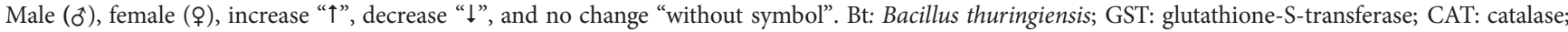
SOD: superoxide dismutase; LPO: lipid peroxidation; GSH: glutathione; T-AOC: total antioxidant capability. 4-HNE: 4-hydroxy-2-nonenal, PAR: poly(ADPribose), PARP: poly(ADP-ribose) polymerase; i.p.: intraperitoneally.

and sperm motility [111]. ABA induced reduction in springs of male rats after expose for 30 days (subacute) and 210 days (subchronic) [63]. Histological alteration in the testes of male rats was recorded after exposure to ABA at doses of 1.19, 1.87, and $2.13 \mathrm{mg} / \mathrm{animal} / \mathrm{day}$ for 180 days. It caused infiltration, congestion in the blood vessels, and hemorrhage [112]. Oral administration of male rats for one week by $1 \mathrm{mg} / \mathrm{kg} / \mathrm{day}$ (low dose) and $4 \mathrm{mg} / \mathrm{kg} /$ day (high dose) for 6 weeks induced changes in spermatogenesis $[113,114]$. It has been reported that ABA can induce histopathological alteration in the testes of male rats, such as degeneration, edema, and necrosis of spermatogonia cells lining seminiferous tubules associated and decreased number of spermatogenic elements $[63,112]$.

Srivastava and Raizada [76] evaluated the reproductive toxicity of azadirachtin on rats throughout postnatal development of rats for two generations. Rats were fed on diet containing azadirachtin at concentrations 100, 500, and $1000 \mathrm{ppm}$ that is corresponding to 5,25 , and $50 \mathrm{mg} / \mathrm{kg}$. b.wt. Results showed no toxic effect of azadirachtin on reproductive function on rats and over two generations. Technical azadirachtin has not produced any adverse effects on reproductive function and data were comparable to control animals over two generations. Administration ABA to rats at dose of $0.4 \mathrm{mg} / \mathrm{kg}$. wt. caused increase in stillbirths and decrease pups viability, lactation, and pups weights. This finding suggests that the ABA could have the possibility of inducing reproductive effects at high enough doses [115]. At dose toxic to mice and rabbit mothers, ABA can cause cleft palate in the offspring [116]. In rat-administered ABA at $1 \mathrm{mg} / \mathrm{kg} / \mathrm{day}$, no birth defects were recorded and the teratogenic effect caused at high toxic doses to mother [115].

Hanley et al. [117] evaluated the reproductive effect of spinosad on rats for two continual generations. Rats were administrated spinosad at doses of 3,10, and $100 \mathrm{mg} / \mathrm{kg}$. b.wt. via diet dally for 2 generations. Treatment with spinosad in diet at high dose $(100 \mathrm{mg} / \mathrm{kg}$. b.wt.) causes maternal toxicity and adverse effect on the offspring. The authors reported no significant effects of spinosad at lower doses. Breslin et al. [69] found the same trend in another study on pregnant rats and rabbits administrated by gavage spinosad at doses of 10, 50, and $200 \mathrm{mg} / \mathrm{kg}$. b.wt. for rats and 2.5, 10, and $50 \mathrm{mg} / \mathrm{kg}$. b.wt. for rabbits, respectively. The authors reported no maternal effect of spinosad at lower doses. Spinosad not induced signs of developmental toxicity at all tested doses. The NOEL (No Observed Effect Levels) of maternal was $50 \mathrm{mg} / \mathrm{kg}$. b.wt. of rats and $10 \mathrm{mg} / \mathrm{kg}$. b.wt of rabbits.

It has been reported that $B t$ do not have any reproductive effects or birth defects in mammals and also no available studies regarding this issue [118]. There are also no available data and studies on the reproductive and developmental toxicity of phosphine [119].

5.6. Oxidative Stress. Oxidative stress is one of the common explanations for the mechanism of toxic action of pesticides, especially when exposed to low doses and for a long time. It is caused because of a disturbance in the balance between antioxidant defenses in the body and the level of free radicals or reactive oxygen species (ROS). Oxidative stress occurs when the level of ROS increases compared to the antioxidant defense mechanisms. When ROS is increased, the damage is occurring to lipid "lipid peroxidation", protein, and genetic materials such as DNA. Moreover, it has played an important role in the damage of cell membrane, cell, tissue, and organ (Table 6). The effect of exposure to spinosad on oxidative stress biomarkers in male rats was evaluated [120]. 
Rats were given spinosad via oral route at dose of $347.49 \mathrm{mg} / \mathrm{kg}$. b.wt. $\left(1 / 20 \mathrm{LD}_{50}\right)$ for four weeks. It caused inhibition in the activity of glutathione-S-transferase (GST), catalase (CAT), and superoxide dismutase (SOD) and level of glutathione $(\mathrm{GSH})$. It caused a decrease in the activity of glutathione peroxidase (GPx) and level of reduced and lipid peroxidation in the liver. The authors suggested that the hepatotoxicity of spinosad could be due to the formation of ROS in hepatic cells. It induced oxidative stress in the liver of Nile tilapia (Oreochromis niloticus) after exposure to 25, 50, and $75 \mathrm{mg} / \mathrm{L}$ for 24, 48, and $72 \mathrm{~h}$ [93]. It causes significant alterations on oxidative stress markers in the liver of Nile tilapia.

Abamectin caused alteration in oxidative stress markers in male and female pups whose mothers are exposed to 22.10, 11.05 , and $2.21 \mathrm{mg} / \mathrm{kg}$. b.wt. during lactation period [60]. The authors reported also changes in kidney tissue structure, especially at high dose. ABA was orally administered to rats at dose of $30 \mathrm{mg} / \mathrm{kg}$. b.wt for 30 days [121]. It caused reduction in the activity of SOD, CAT, GST, and GSH and increase in the level of these biomarkers in kidney and brain of treated rats. Other studies also reported oxidative stress induced by abamectin in testis of male rats [113] and in the spleen of pigeon [122]. The effect of ABA on brain of rats was studied by Abdel-Razik and Hamed [64]. Rats were orally administered ABA at dose of $3.3 \mathrm{mg} / \mathrm{kg}$. b.wt. as single dose and oxidative stress (SOD, GSH, and LPO) was determined after 4, 24, and $36 \mathrm{~h}$ of treatment. ABA induced oxidative stress that caused a significant reduction in SOD activity and level of GSH. It caused also significant increase in the level of LPO. Hmani et al. [123] evaluated the oral toxicity of $B t$ toxin (Vip3Aa16) on oxidative stress in liver and kidney of mice. Mice were administrated Bt toxin at dose of 2500, 5000, and $7500 \mathrm{mg} / \mathrm{kg}$. b.wt. for 14 days. There were no significant changes in oxidative stress parameters such as SOD, $\mathrm{H}_{2} \mathrm{O}_{2}$ (hydrogen peroxide) and LPO in the liver and kidney of exposed mice.

Phosphine (produced from aluminum, magnesium, and zinc phosphide) was evaluated for toxic effects on male rats [124]. Rats were administered intraperitoneally (i.p.) with phosphine at dose of $4 \mathrm{mg} / \mathrm{kg}$. b.wt. as single dose; the kidney and heart were taken after 30 min of exposure. Phosphine induced significant reduction in the level of GSH and activity of SOD, CAT, and GPx. It caused a significant increase in LPO in both tissues. In another study by the same authors [125], rats were treated i.p. with phosphine at dose of $2 \mathrm{mg} / \mathrm{kg}$. b.wt. and oxidative stress parameters were evaluated in brain, liver, and lung after 3 mint of treatment. $\mathrm{PH}_{3}$ induced significant reduction in GSH and the increase in LPO concentration.

5.7. Neurotoxicity. The toxic effect of some insecticides in the nervous system was reported both in insects and in mammals. Most insecticides with neurotoxicity are not highly selective and cause neurotoxic effect to nontarget organisms such as beneficial insects, animals and humans. It has been reported that insecticides cause neurotoxicity and kill insects by an effect on their nervous system and can also induce neurotoxic effect in animals and humans. The neurotoxic effect of most insecticides can be induced their acute toxicity at high dose of exposure or can cause chronic neurodegenerative diseases such as Parkinson's disease [126]. The mechanism of neurotoxicity of some natural insecticides was reported. For example, pyrethrins are neurotoxicant [23], affect sodium channels [24], and affect gamma amino butyric acid (GABA) [26]. Spinosad is a neurotoxin and the effect on the nicotinic acetylcholine receptor and gamma amino butyric acid (GABA) receptor [16] in the site different from imidacloprid and nicotine. The ABA has an effect on the nervous system by blocking the ion tropic $\alpha$-amino butyric acid (GABA) [35]. Phosphine also has neurotoxicity and causes nerve poison [27].

It has been reported that pyrethrins are poisonous insecticides to animals and humans [127]. It caused neurotoxic action in the nerves system [23] and effect on animals activities. For example, rats administered pyrethrins showed some signs of toxicity, e.g., difficulty or quick inhalation, incoordination, unbalanced, tremors, aggression, and sensitivity to external stimuli [128].

Male and female rats were administered abamectin at dose of $0.5,1.5$, and $6 \mathrm{mg} / \mathrm{kg}$. b.wt. as single oral dose and observed for 14 days [129]. ABA caused signs of neurotoxicity that persisted in some female rats after two or three days of treatment and reduced motor activity. It caused decrease in brain weight in female rats but without any histopathological changes [130]. Other studies reported neurotoxic effects of ABA in experimental animals, especially at high doses. The developmental neurotoxicity by ABA (emamectin benzoate) was recorded in the $\mathrm{F}_{1}$ offspring whose mother exposed to ABA during gestation and lactation periods. The authors reported that the NOAEL is $0.6 \mathrm{mg} / \mathrm{kg} /$ day for developmental neurotoxicity of ABA [131].

Marrs [132] reported that spinosad has not specific neurotoxicity in experimental animals such as rats in acute and chronic studies. The author also reported that the toxic effect of spinosad is closely similar to toxic effect of spinosad A. Spinosad did not induce neurotoxicity in acute, subacute, and chronic toxicity studies in rats. According to the US EPA [133], spinosad did not cause neurotoxicity in rats in acute, subchronic, or chronic toxicity studies.

Previous studies showed that phosphine could inhibit acetylcholine esterase (AChE), which lead to increase the neurotransmitter acetylcholine $[134,135]$. Phosphine like other OPIs caused inhibition in AChE and neurotoxicity in mammals. In inhalation exposure, phosphine induced neurotoxicity in rats after acute and subchronic (90 days) exposure. The NOAEL was $38 \mathrm{ppm}$ in the acute neurotoxicity study [136].

5.8. Mutagenicity and Genotoxicity. Mutagenicity in general means that all chemicals or physical agents are able to induce changes in the genetic material, usually deoxyribonucleic acid DNA in organism, e.g., bacteria, animals, humans, and others. This change leads to increases in the rate of mutations over the natural level. In contrast, genotoxicity means the ability of chemical agents to induce damage in the genetic materials that lead to loss of genetic information 
in cell and inducing mutations that could lead to cancer. In this regard, not all genotoxic agents are mutagens but all mutagens are genotoxic agents. ABA does not seem to be mutagenic. It has a negative mutagenic effect in mice and rats. Moreover, it is shown to be nonmutagenic in the Ames test [137]. Indifference, abamectin has potential genotoxic effects on the Chinese hamster ovary (CHOK1) cells [138]. Spinosad has been reported no mutagenic effect by EPA [139] while Mansour et al. [71] found that spinosad has genotoxic effect in rat bone marrow cells. The authors explain the genotoxic effect of spinosad is due to the active ingredient and or the inert materials used in insecticide formulation. None of the genotoxicity studies showed mutagenic activity associated with spinosad [132]. de Souza Freire et al. [104] evaluated three Cry-endotoxins (BtCrylla, BtCryl0Aa, and BtCrylBa6) from $B t(B t)$ on mice to study their effect on genetic material. The three tested endotoxins did not induce any changes in micronucleus and polychromatic erythrocytes in mice. Phosphine gas is not clastogenic and does not induce mutations in mice after exposure to 14 days [140]. However, phosphine does not cause cytogenetic effects in experimental animals such as male mice and rats after subacute exposure (11-12 days) [141]. Limited data about the genotoxic effect of natural pyrethrins was found. Negative results were recorded of natural pyrethrins by using the Ames test on Salmonella and Escherichia coli [142]. In addition, it has been reported that pyrethrin did not induce gene mutation in mice and at high concentration and the frequency of mutation was significant increase [143]. In contrast, several studies reported mutagenic and genotoxic effect of synthetic pyrethroids on experimental animals [84, 144, 145].

Neem extract (most active compound is azadirachtin) was evaluated for cytogenetic in murine germ cells [146]. The extract caused an increase in chromosomal aberration of spermatocytes and increase up normal sperms. Therefore, azadirachtin can induce mutagenicity and genotoxicity. In another study on male mice, crude leaf extract of neem (Azadirachta indica) at dose of 0.5, 1.0, and $2.0 \mathrm{~g} / \mathrm{kg}$. b.wt. for one week induced chromosomal aberration in bone marrow [147].

5.9. Carcinogenicity. A carcinogen means that any material can promote carcinogenesis (formation of cancer). This effect can be due to the ability of this substance to induce damage in the genome and or to the disturbance of cellular metabolic processes. Pyrethrins were studied for carcinogenicity on experimental animals. In one of these studies, rats were exposed to pyrethrins (plant extract) at doses of 100, 1000, and $3000 \mathrm{mg} / \mathrm{kg}$. b.wt. (moderate and very high doses) through feeding for 104 weeks. Pyrethrins increased the noncancerous (benign) thyroid tumors in females at all doses and in males at high to very high doses [148]. The same authors reported that pyrethrins induced development in ovarian and benign liver tumors in female rats fed on high doses $(3000 \mathrm{mg} / \mathrm{kg}$. b.wt.). This dose developed benign parathyroid tumors and benign skin lesions in male rats [148]. In a different study, pyrethrins at dose less than $10 \mathrm{mg} / \mathrm{kg}$. b.wt. showed no increase in tumor in rats [128]. Therefore, US EPA classified pyrethrins as "likely to be carcinogenic to humans by the oral route" [148].
It has been reported that abamectin is not carcinogenic in mice and rats [116]. Also, according to US EPA [51], ABA is noncarcinogenic to human and classified in-group E. Spinosad was also classified as noncarcinogenic to mice and rats [132]. In another study spinosad was not carcinogenic to male and female rats at dose near to $0.05 \%$ [70]. There is no available information regarding the carcinogenic effect of phosphine in human. Moreover, rats exposed to phosphine via diets showed no carcinogenic effect $[140,148]$. Therefore, EPA [140] has not classified phosphine as human carcinogenicity (Group D). Bt does not have any chronic toxicity and carcinogenic effects [118]. There is also no indication that $B t$ causes reproductive effects or birth defects in mammals.

\section{Natural Insecticides and Organic Farmers}

From this review and previous studies, it can be reported that some natural insecticides have adverse toxic effects in experimental animals. It can induce alterations in biochemical, hormonal, reproductive, and oxidative stress biomarkers. It causes also cytotoxic, autogenetic, genotoxic, and carcinogenic effects in experimental animals $[60,71,78,118,148]$. Therefore, some natural compounds not safe and the term "natural" not mean compounds are safe.

\section{Conclusion}

The natural insecticide content is botanical insecticides (e.g., pyrethrins and azadirachtin), microbial insecticides (e.g., Bacillus thuringiensis, Lecanicillium muscarium, abamectin, and spinosad), mineral oils, and minerals. The selectivity and safety of natural insecticides are not absolute and some natural compounds are toxic and induced adverse effects to experimental animals. It can induce hepatotoxicity, renal toxicity, hematotoxicity, reproductive toxicity, neurotoxicity, and oxidative stress. It can induce mutagenicity, genotoxicity, and carcinogenicity in mammals. Some natural insecticides and active compounds from essential oils are classified in categories $\mathrm{Ib}$ (Highly hazardous) to $\mathrm{U}$ (unlikely toxic). Therefore, all natural insecticides are not safe and the term "natural" does not mean that compounds are safe. In this respect, the term "natural" is not synonymous with "organic" and not all-natural insecticide products are acceptable in organic farmers.

\section{Conflicts of Interest}

The authors declare no conflicts of Interest.

\section{References}

[1] K. M. Blindauer, R. J. Jackson, M. McGeehin, C. Pertowski, and C. Rubin, "Environmental pesticide illness and injury: The need for a national surveillance system," Journal of Environmental Health, vol. 61, no. 10, p. 9, 1999.

[2] C. Tomlin, The Pesticide Manual, British Crop Protection Council, Farnham, Surrey, UK, 12th edition, 2000.

[3] C. D. S. Tomlin, The Pesticide Manual, The British Crop Protection Council, London, UK, 17 edition, 2015. 
[4] A. De, R. Bose, A. Kumar, and S. Mozumdar, Targeted delivery of pesticides using biodegradable polymeric nanoparticles, Springer, 2014.

[5] M. Akhgari, M. Abdollahi, A. Kebryaeezadeh, R. Hosseini, and O. Sabzevari, "Biochemical evidence for free radical-induced lipid peroxidation as a mechanism for subchronic toxicity of malathion in blood and liver of rats," Human \& Experimental Toxicology, vol. 22, no. 4, pp. 205-211, 2003.

[6] J. A. Patil, A. J. Patil, A. V. Sontakke, and S. P. Govindwar, "Effect of methomyl on hepatic mixed function oxidases in rats," Indian Journal of Pharmacology, vol. 40, no. 4, pp. 158-163, 2008.

[7] A. T. Farag, A. M. El Okazy, and A. F. El-Aswed, "Developmental toxicity study of chlorpyrifos in rats," Reproductive Toxicology, vol. 17, no. 2, pp. 203-208, 2003.

[8] F. Ngoula, P. Watcho, M.-C. Dongmo, A. Kenfack, P. Kamtchouing, and J. Tchoumboue, "Effects of pirimiphos-methyl (an organophosphate insecticide) on the fertility of adult male rats," African Health Sciences, vol. 7, no. 1, pp. 3-9, 2007.

[9] Y. S. Al-Awthan, M. A. Al-Douis, G. H. El-Sokkary, and E. M. Aqlan, "Dimethoate-induced Oxidative Stress and Morphological Changes in the Liver of Guinea Pig and the Protective Effect of Vitamin C and E," Asian Journal of Biological Sciences, vol. 5, no. 1, pp. 9-19, 2012.

[10] I. Soni, F. Syed, P. Bhatnagar, and R. Mathur, "Perinatal toxicity of cyfluthrin in mice: Developmental and behavioral effects," Human \& Experimental Toxicology, vol. 30, no. 8, pp. 1096-1105, 2011.

[11] M. A. Abbassy, A. E.-S. M. Marei, M. A. M. Al-Ashkar, and A.T. H. Mossa, "Adverse biochemical effects of various pesticides on sprayers of cotton fields in El-Behira Governorate, Egypt," Biomedicine \& Aging Pathology, vol. 4, no. 3, pp. 251-256, 2014.

[12] R. Doll and R. Peto, "The causes of cancer: quantitative estimates of avoidable risks of cancer in the United States today," Journal of the National Cancer Institute, vol. 66, no. 6, pp. 11921308, 1981.

[13] R. A. Dybas, "Abamectin use in crop protection," in Ivermectin And Abamectin, pp. 287-310, Springer, 1989.

[14] D. G. Nielsen, "Evaluation of biorational pesticides for use in arboriculture," Journal of Arboriculture, vol. 16, no. 4, pp. 82-88, 1990.

[15] P. DeBach and D. Rosen, Biological Control by Natural Enemies, CUP Archive, 1991.

[16] V. L. Salgado, "Studies on the mode of action of Spinosad: Insect symptoms and physiological correlates," Pesticide Biochemistry and Physiology, vol. 60, no. 2, pp. 91-102, 1998.

[17] L. A. Lacey, R. Frutos, H. K. Kaya, and P. Vail, "Insect pathogens as biological control agents: Do they have a future?” Biological Control, vol. 21, no. 3, pp. 230-248, 2001.

[18] R. A. Cloyd, C. L. Galle, S. R. Keith, N. A. Kalscheur And, and K. E. Kemp, "Effect of commercially available plant-derived essential oil products on arthropod pests," Journal of Economic Entomology, vol. 102, no. 4, pp. 1567-1579, 2009.

[19] J. L. Jurat-Fuentes and T. A. Jackson, "Bacterial Entomopathogens," in Insect Pathology, F. E. Vega and H. K. Kaya, Eds., pp. 265-304, Academic Press, San Francisco, USA, 2012.

[20] World Health Organization (WHO), The WHO Recommended Classification of Pesticides by Hazard And Guidelines to Classification, 2010.

[21] G. D. Todd, D. Wohlers, and M. J. Citra, Toxicological Profile for Pyrethrins And Pyrethroids, 2003.
[22] C. Bond, K. Buhl, and D. Stone, Pyrethrins General Fact Sheet, National Pesticide Information Center, Oregon State University Extension Services, 2014, http://npic.orst.edu/factsheets/ pyrethrins.html.

[23] W. N. Aldridge, "An assessment of the toxicological properties of pyrethroids and their neurotoxicity," Critical Reviews in Toxicology, vol. 21, no. 2, pp. 89-104, 1990.

[24] H. P. M. Vijverberg, J. M. Van Der Zalm, and J. Van Den Bercken, "Similar mode of action of pyrethroids and DDT on sodium channel gating in myelinated nerves," Nature, vol. 295, no. 5850, pp. 601-603, 1982.

[25] S. P. Bradbury and J. R. Coats, "Comparative toxicology of the pyrethroid insecticides," Reviews of Environmental Contamination and Toxicology, vol. 108, pp. 133-177, 1989.

[26] S. N. Mandhane and C. T. Chopde, "Neurobehavioral effects of low level fenvalerate exposure in mice," Indian Journal of Experimental Biology (IJEB), vol. 35, no. 6, pp. 623-627, 1997.

[27] C. D. S. Tomlin, The e-Pesticide Manual, The British Crop Protection Council, London, UK, 2005.

[28] A. J. Mordue (Luntz) and A. J. Nisbet, "Azadirachtin from the neem tree Azadirachta indica: its action against insects," Anais da Sociedade Entomologica do Brasil, vol. 29, no. 4, pp. 615-632, 2000.

[29] J. H. Butterworth and E. D. Morgan, "Isolation of a substance that suppresses feeding in locusts," Chemical Communications (London), no. 1, pp. 23-24, 1968.

[30] A. J. Mordue and A. Blackwell, "Azadirachtin: an update," Journal of Insect Physiology, vol. 39, no. 11, pp. 903-924, 1993.

[31] F. R. Mertz and R. C. Yao, "Saccharopolyspora spinosa sp. nov. isolated from soil collected in a sugar mill rum still," International Journal of Systematic and Evolutionary Microbiology, vol. 40, no. 1, pp. 34-39, 1990.

[32] M. A. Mayes, G. D. Thompson, B. Husband, and M. M. Miles, "Spinosad toxicity to pollinators and associated risk," Reviews of Environmental Contamination and Toxicology, vol. 179, Springer, pp. 37-71, 2003.

[33] H. A. Kirst, "The spinosyn family of insecticides: Realizing the potential of natural products research," The Journal of Antibiotics, vol. 63, no. 3, pp. 101-111, 2010.

[34] A. K. Agarwal, "Avermectin," in Encyclopedia of Toxicology, P. Wexler, Ed., pp. 89-90, Academic, San Diego, CA, USA, 1998.

[35] L. Kolar, N. Kožuh Eržen, L. Hogerwerf, and C. A. M. van Gestel, "Toxicity of abamectin and doramectin to soil invertebrates," Environmental Pollution, vol. 151, no. 1, pp. 182-189, 2008.

[36] E. H. Smith, "Tree spray oils," in Agricultural Applications of Petroleum Products, Advances in Chemistry Series, pp. 3-11, 1952.

[37] M. Buteler and T. Stadler, "A review on the mode of action and current use of petroleum distilled spray oils," in Pesticides in the modern world-pesticides use and management, InTech, 2011.

[38] H. Höfte and H. R. Whiteley, "Insecticidal crystal proteins of Bacillus thuringiensis," Microbiology Reviews, vol. 53, no. 2, pp. 242-255, 1989.

[39] M. A. Ibrahim, N. Griko, M. Junker, and L. A. Bulla, "Bacillus thuringiensis A genomics and proteomics perspective," Bioengineered Bugs, vol. 1, no. 1, pp. 31-50, 2010.

[40] S. Ali, C. Zhang, Z. Wang et al., "Toxicological and biochemical basis of synergism between the entomopathogenic fungus Lecanicillium muscarium and the insecticide matrine against Bemisia tabaci (Gennadius)," Scientific Reports, vol. 7, no. 1, Article ID 46558, 2017. 
[41] L. Wang, J. Huang, M. You, and B. Liu, “Time-dose-mortality modelling and virulence indices for six strains of Verticillium lecanii against sweetpotato whitefly, Bemisia tabaci (Gennadius)," Journal of Applied Entomology, vol. 128, no. 7, pp. 494500, 2004.

[42] R. Anand and B. N. Tiwary, "Pathogenicity of entomopathogenic fungi to eggs and larvae of Spodoptera litura, the common cutworm," Biocontrol Science and Technology, vol. 19, no. 9, pp. 919-929, 2009.

[43] R. Anand, B. Prasad, and B. N. Tiwary, "Relative susceptibility of Spodoptera litura pupae to selected entomopathogenic fungi," BioControl, vol. 54, no. 1, pp. 85-92, 2009.

[44] S. Güçlü, K. Ak, C. Eken et al., "Pathogenicity of Lecanicillium muscarium against Ricania simulans," Bulletin of Insectology, vol. 63, no. 2, pp. 243-246, 2010.

[45] G. Gindin, I. Barash, N. Harari, and B. Raccah, "Effect of endotoxic compounds isolated from Verticillium lecanii on the sweetpotato whitefly, Bemisia tabaci," Phytoparasitica, vol. 22, no. 3, pp. 189-196, 1994.

[46] M. B. Isman, "Plant essential oils for pest and disease management," Crop Protection, vol. 19, no. 8-10, pp. 603-608, 2000.

[47] O. Koul, S. Walia, and G. S. Dhaliwal, "Essential oils as green pesticides: Potential and constraints," Biopesticides International, vol. 4, no. 1, pp. 63-84, 2008.

[48] A.-T. H. Mossa, "Green Pesticides: Essential oils as biopesticides in insect-pest management," Journal of Environmental Science and Technology, vol. 9, no. 5, pp. 354-378, 2016.

[49] S. Dev and O. Koul, Insecticides of natural origin Harwood Academic Publishers Amsterdam p. 365, 1997.

[50] P. Golob, "The use of spices and medicinals as bioactive protectants for grains," Food \& Agriculture Organization, vol. 137, pp. 201-213, 1999.

[51] USEPA, Office of Pesticide Programs, Health Effects Division, Science Information Management Branch: "Chemicals Evaluated for Carcinogenic Potential", 2006.

[52] A. C. Springfield, G. P. Carlson, and J. J. DeFeo, "Liver enlargement and modification of hepatic microsomal drug metabolism in rats by pyrethrum," Toxicology and Applied Pharmacology, vol. 24, no. 2, pp. 298-308, 1973.

[53] K. R. Desai, N. Moid, P. B. Patel, and H. N. Highland, "Evaluation of Deltamethrin induced reproductive toxicity in male Swiss Albino mice," Asian Pacific Journal of Reproduction, vol. 5, no. 1, pp. 24-30, 2016.

[54] K. K. Grewal, G. S. Sandhu, R. Kaur, R. S. Brar, and H. S. Sandhu, "Toxic impacts of cypermethrin on behavior and histology of certain tissues of albino rats," Toxicology International, vol. 17, no. 2, pp. 94-98, 2010.

[55] P. E. Newton, R. E. Schroeder, J. B. Sullivan, W. M. Busey, and D. A. Banas, "Inhalation toxicity of phosphine in the rat: Acute, subchronic, and developmental," Inhalation Toxicology, vol. 5, no. 2, pp. 223-239, 1993.

[56] H. Rehman, A. T. Aziz, S. Saggu, Z. K. Abbas, A. Mohan, and A. A. Ansari, "Systematic review on pyrethroid toxicity with special reference to deltamethrin," Journal of Entomology And Zoology Studies, vol. 2, no. 6, pp. 60-70, 2014.

[57] K. S. El-Gendy, N. M. Aly, F. H. Mahmoud, D. M. Abd Allah, and A. K. H. El-Sebae, "Hepatotoxicity and Nephrotoxicity in Mice Induced by Abamectin and Ameliorating Effect of Quercetin," Asian Journal of Agricultural and Food Sciences, vol. 3, pp. 651666, 2015.
[58] L. L. Bailey, T. R. Simons, and K. H. Pollock, "Estimating site occupancy and species detection probability parameters for terrestrial salamanders," Ecological Applications, vol. 14, no. 3, pp. 692-702, 2004.

[59] S. A. Mansour and A.-T. H. Mossa, "Oxidative damage, biochemical and histopathological alterations in rats exposed to chlorpyrifos and the antioxidant role of zinc," Pesticide Biochemistry and Physiology, vol. 96, no. 1, pp. 14-23, 2010.

[60] A.-T. H. Mossa, M. A. Abdel Rasoul, and S. M. M. Mohafrash, "Lactational exposure to abamectin induced mortality and adverse biochemical and histopathological effects in suckling pups," Environmental Science and Pollution Research, vol. 24, no. 11, pp. 10150-10165, 2017.

[61] A. Goel, V. Dani, and D. K. Dhawan, "Protective effects of zinc on lipid peroxidation, antioxidant enzymes and hepatic histoarchitecture in chlorpyrifos-induced toxicity," ChemicoBiological Interactions, vol. 156, no. 2-3, pp. 131-140, 2005.

[62] A.-T. H. Mossa, A. A. Refaie, and A. Ramadan, "Effect of exposure to mixture of four organophosphate insecticides at no observed adverse effect level dose on rat liver: the protective role of vitamin C," Research Journal of Environmental Toxicology, vol. 5, no. 6, pp. 323-335, 2011.

[63] H. K. Abd-Elhady and G. E. Abou-Elghar, "Abamectin induced biochemical and histopathological changes in the albino rat, rattus norvegicus," Journal of Plant Protection Research, vol. 53, no. 3, pp. 263-270, 2013.

[64] R. K. Abdel-Razik and N. A. Hamed, "Deleterious effect of abamectin on rat brain mitochondria," Alexandria Science Exchange Journal: An International Quarterly Journal of Science Agricultural Environments, vol. 36, no. 4, pp. 422-428, 2015.

[65] A. G. Canga, A. M. S. Prieto, M. J. D. Liébana, N. F. Martínez, M. S. Vega, and J. J. G. Vieitez, "The pharmacokinetics and metabolism of ivermectin in domestic animal species," The Veterinary Journal, vol. 179, no. 1, pp. 25-37, 2009.

[66] M. S. Maynard, P. G. Wislocki, and T. A. Jacob, "Metabolism of avermectin Bla in goats. Merck sharp and dohme research laboratories," CDFA, pp. 50406-50476, 1985.

[67] S. Merck and (MSD) Dohme, "MX-933: Metabolism study in the rat. Study NO. TT \#79-711-0, CDFA, pp. 50406-504147," 1980.

[68] S. A. El-Naggar, H. Eltantawi, M. A. Ibrahim, and A. AlmEldeen, "Assessment of the toxicity of sub-chronic low and high doses of the bio-insecticide spinosad on the liver, kidney and the cerebellum in male albino mice," Brazilian Archives of Biology and Technology, vol. 60, 2017.

[69] W. J. Breslin, M. S. Marty, U. Vedula, A. B. Liberacki, and B. L. Yano, "Developmental toxicity of Spinosad administered by gavage to $\mathrm{CD}^{\circledR}$ rats and New Zealand White rabbits," Food and Chemical Toxicology, vol. 38, no. 12, pp. 1103-1112, 2000.

[70] B. L. Yano, D. M. Bond, M. N. Novilla, L. G. McFadden, and M. J. Reasor, "Spinosad insecticide: Subchronic and chronic toxicity and lack of carcinogenicity in Fischer 344 rats," Toxicological Sciences, vol. 65, no. 2, pp. 288-298, 2002.

[71] S. A. Mansour, A. H. Mossa, and T. M. Heikal, "Cytogenetic and hormonal alteration in rats exposed to recommended "safe doses" of spinosad and malathion insecticides," International Journal of Agriculture \& Biology, vol. 10, no. 1, 2008.

[72] A. Ibegbu, A. Babatunde, A. Alatise et al., "Effects of vitamin E administration on phostoxin-induced changes in the kidney of adult Wistar rats," Journal of Experimental and Clinical Anatomy, vol. 12, no. 2, p. 62, 2013. 
[73] H. Türkez and B. Toğar, "Aluminum phosphide-induced genetic and oxidative damages in rats: Attenuation by Laurus nobilis leaf extract," Toxicology \& Industrial Health, vol. 29, no. 7, pp. 579-583, 2013.

[74] S. Shakeri and O. Mehrpour, "Aluminum phosphide poisoning in animals," International Journal of Medical Toxicology and Forensic Medicine, vol. 5, no. 2, pp. 81-97, 2014.

[75] R. B. Raizada, M. K. Srivastava, R. A. Kaushal, and R. P. Singh, "Azadirachtin, a neem biopesticide: subchronic toxicity assessment in rats," Food and Chemical Toxicology, vol. 39, no. 5, pp. 477-483, 2001.

[76] M. K. Srivastava and R. B. Raizada, "Lack of toxic effect of technical azadirachtin during postnatal development of rats," Food and Chemical Toxicology, vol. 45, no. 3, pp. 465-471, 2007.

[77] S. M. Meher, S. L. Bodhankar, J. N. Dhuley, D. J. Khodape, and S. R. Naik, "Toxicity studies of microbial insecticide Bacillus thuringiensis var. kenyae in rats, rabbits, and fish," International Journal of Toxicology, vol. 21, no. 2, pp. 99-105, 2002.

[78] F. Eissa and N. Zidan, "Haematological, biochemical and histopathological alterations induced by abamectin and bacillus thuringiensis in male albino rats," Acta Biologica Hungarica, vol. 61, no. 1, pp. 33-44, 2010.

[79] N. Anderson and J. Borlak, "Hepatotoxicity: From Genomics to in Vitro And in Vivo Models," in Hepatotoxicity: From Genomics to in vitro and in vivo Models, S. C. Sahu, Ed., p. 192, John Wiley \& Sons, 2007.

[80] H. M. Mehendale, “Tissue Repair: AN Important Determinant of Final Outcome of Toxicant-Induced Injury," Toxicologic Pathology, vol. 33, no. 1, pp. 41-51, 2005.

[81] D. L. Laskin and K. J. Pendino, "Macrophages and inflammatory mediators in tissue injury," Annual Review of Pharmacology and Toxicology, vol. 35, no. 1, pp. 655-677, 1995.

[82] G. Poli, "Liver damage due to free radicals," British Medical Bulletin, vol. 49, no. 3, pp. 604-620, 1993.

[83] J. Wayland and J. R. Hayer, Pesticides Studied in Man, pp. 133-135, Williams \& Wilkins, Baltimore, USA, 1982.

[84] A.-T. H. Mossa, A. A. Refaie, A. Ramadan, and J. Bouajila, "Antimutagenic effect of Origanum majorana L. essential oil against prallethrin-induced genotoxic damage in rat bone marrow cells," Journal of Medicinal Food, vol. 16, no. 12, pp. 11011107, 2013.

[85] H. A. Ogaly, A. A. Khalaf, M. A. Ibrahim, M. K. Galal, and R. M. Abd-Elsalam, "Influence of green tea extract on oxidative damage and apoptosis induced by deltamethrin in rat brain," Neurotoxicology and Teratology, vol. 50, pp. 23-31, 2015.

[86] A.-T. H. Mossa, T. M. Heikal, M. Belaiba, E. G. Raoelison, H. Ferhout, and J. Bouajila, "Antioxidant activity and hepatoprotective potential of Cedrelopsis grevei on cypermethrin induced oxidative stress and liver damage in male mice," $B M C$ Complementary and Alternative Medicine, vol. 15, no. 1, 2015.

[87] H. Khaldoun-Oularbi, C. Richeval, N. Djenas, M. Lhermitte, L. Humbert, and A. Baz, "Effect of sub-acute exposure to abamectin "insecticide" on liver rats (Rattus norvegicus)," Annales de Toxicologie Analytique, vol. 25, no. 2, pp. 63-70, 2013.

[88] J. Dupuy, A. Lespine, J. F. Sutra, and M. Alvinerie, "The interaction between moxidectin and MDR transporters in primary cultures of rat hepatocytes," Journal of Veterinary Pharmacology and Therapeutics, vol. 29, no. 2, pp. 107-111, 2006.

[89] D.-Z. Hsu, C.-H. Hsu, B.-M. Huang, and M.-Y. Liu, "Abamectin effects on aspartate aminotransferase and nitric oxide in rats," Toxicology, vol. 165, no. 2-3, pp. 189-193, 2001.
[90] N. E.-H. A. Zidan, "Hepato-and nephrotoxicity in male albino rats exposed to Malathion and spinosad in stored wheat grains," Acta Biologica Hungarica, vol. 66, no. 2, pp. 133-148, 2015.

[91] S. A. Mansour, A. H. Mossa, and T. M. Heikal, "Haematoxicity of a new natural insecticide spinosad on male albino rats," International Journal of Agriculture \& Biology, vol. 9, no. 2, pp. 342-346, 2007.

[92] K. E. Stebbins, D. M. Bond, M. N. Novilla, and M. J. Reasor, "Spinosad insecticide: Subchronic and chronic toxicity and lack of carcinogenicity in CD-1 mice," Toxicological Sciences, vol. 65, no. 2, pp. 276-287, 2002.

[93] P. Piner and N. Üner, "Oxidative stress and apoptosis was induced by bio-insecticide spinosad in the liver of Oreochromis niloticus," Environmental Toxicology and Pharmacology, vol. 36, no. 3, pp. 956-963, 2013.

[94] A. J. J. M. Lemos, H. A. A. Siqueira, V. Wanderley-Teixeira et al., "Effect of sub-lethal doses of Bacillus thuringiensis subsp. Aizawai and deltamethrin with regard to fertility and organ toxicity in pregnant albino rats," Experimental and Toxicologic Pathology, vol. 65, no. 5, pp. 489-495, 2013.

[95] N. Z. Shaban, M. H. Helmy, M. A. R. El-Kersh, and B. F. Mahmoud, "Effects of Bacillus thuringiensis toxin on hepatic lipid peroxidation and free-radical scavengers in rats given alpha-tocopherol or acetylsalicylate," Comparative Biochemistry and Physiology - C Toxicology and Pharmacology, vol. 135, no. 4, pp. 405-414, 2003.

[96] S. Kitada, Y. Abe, H. Shimada et al., "Cytocidal actions of parasporin-2, an anti-tumor crystal toxin from Bacillus thuringiensis," The Journal of Biological Chemistry, vol. 281, no. 36, pp. 26350-26360, 2006.

[97] R. Anand, P. Kumari, A. Kaushal et al., "Effect of acute aluminum phosphide exposure on rats-A biochemical and histological correlation," Toxicology Letters, vol. 215, no. 1, pp. 62-69, 2012.

[98] G. P. Schoenig, "Mammalian toxicology of pyrethrum extract," in Pyrethrum Flowers: Production, Chemistry, Toxicology, And Uses, J. E. Casida and G. B. Quistad, Eds., pp. 249-257, Oxford University Press, New York, NY, USA, 1995.

[99] H. I. Fahim, O. M. Ahmed, M. W. Boules, and H. Y. Ahmed, "Nephrotoxic effects of abamectin and Calotropis procera latex and leaf extract in male albino rats," American Journal of Medicine and Medical Sciences, vol. 6, no. 3, pp. 73-86, 2016.

[100] Luciane Mourão Guimarães, Davi Felipe Farias, Relinda Campos Carvalho Muchagata et al., "Short-Term Evaluation in Growing Rats of Diet Containing Bacillus thuringiensis CrylIa12 Entomotoxin: Nutritional Responses and Some Safety Aspects," BioMed Research International, vol. 2010, Article ID 630267, 8 pages, 2010.

[101] D. L. Morgan, M. P. Moorman, M. R. Elwell et al., "Inhalation toxicity of phosphine for fischer 344 rats and b6c3f1 mice," Inhalation Toxicology, vol. 7, no. 2, pp. 225-238, 1995.

[102] E. F. S. Authority, "Conclusion on the peer review of the pesticide risk assessment of the active substance Pepino mosaic virus strain CH2 isolate 1906," EFSA Journal, vol. 13, no. 1, 2015.

[103] J. P. Siegel, "The mammalian safety of Bacillus thuringiensisbased insecticides," Journal of Invertebrate Pathology, vol. 77, no. 1, pp. 13-21, 2001.

[104] I. De Souza Freire, A. L. Miranda-Vilela, L. C. P. Barbosa, E. S. Martins, R. G. Monnerat, and C. K. Grisolia, "Evaluation of cytotoxicity, Genotoxicity and hematotoxicity of the recombinant spore-crystal complexes CrylIa, Cryl0Aa and CrylBa6 
from bacillus thuringiensis in swiss mice," Toxins, vol. 6, no. 10, pp. 2872-2885, 2014.

[105] V. D. Hauschild, "Chemical exposure guidelines for deployed military personnel," Drug and Chemical Toxicology, vol. 23, no. 1, pp. 139-153, 2000.

[106] A. A. M. El-Shafey, M. M. E. Seliem, F. El-Mahrouky, W. M. Gabr, and R. A. Kandil, "Some physiological and biochemical effects of Oshar extract and abamectin biocide on male albino rats," Journal of American Science, vol. 7, no. 12, pp. 254-261, 2011.

[107] S. Chatterjee, P. Basak, M. Chaklader et al., "Pesticide induced marrow toxicity and effects on marrow cell population and on hematopoietic stroma," Experimental and Toxicologic Pathology, vol. 65 , no. 3, pp. 287-295, 2013.

[108] B. W. Magdy, F. E. Mohamed, A. S. Amin, and S. S. Rana, "Ameliorative effect of antioxidants (vitamins $\mathrm{C}$ and $\mathrm{E}$ ) against abamectin toxicity in liver, kidney and testis of male albino rats," The Journal of Basic \& Applied Zoology, vol. 77, pp. 69-82, 2016.

[109] C. D. of P. R. (CDPR), CDPR Database - Available Toxicology Summaries, 2005.

[110] G. Vettorazzi, International Regulatory Aspects for Pesticide Chemistry, 1979.

[111] A. I. Eissa, S. M. Khalil, M. M. Farid, and H. E. Frarid, "Biochemical and physiological changes in some organs of albino rats treated with the biopesticide abamectin," Journal of Agriculture Mansoura University, vol. 28, no. 11, pp. 6991-6999, 2003.

[112] A. Elbetieha and S. I. Da'as, "Assessment of antifertility activities of abamectin pesticide in male rats," Ecotoxicology and Environmental Safety, vol. 55, no. 3, pp. 307-313, 2003.

[113] C. Celik-Ozenci, A. Tasatargil, M. Tekcan et al., "Effects of abamectin exposure on male fertility in rats: Potential role of oxidative stress-mediated poly(ADP-ribose) polymerase (PARP) activation," Regulatory Toxicology and Pharmacology, vol. 61, no. 3, pp. 310-317, 2011.

[114] C. Celik-Ozenci, A. Tasatargil, M. Tekcan et al., "Effect of abamectin exposure on semen parameters indicative of reduced sperm maturity: A study on farmworkers in Antalya (Turkey)," Andrologia, vol. 44, no. 6, pp. 388-395, 2012.

[115] U. S. E. P. Agency, Pesticide Fact Sheet Number 89.2: Avermectin B1, Office of Pesticides and Toxic Substances, Washington, DC, USA, 1990.

[116] G. R. Lankas and L. R. Gordon, "Toxicology in WC Campbell (ed.)," in Ivermectin and Abamectin, Springer-Verlag, NY, USA, 1989.

[117] T. R. Hanley, W. J. Breslin, J. F. Quast, and E. W. Carney, “Evaluation of spinosad in a two-generation dietary reproduction study using Sprague-Dawley rats," Toxicological Sciences, vol. 67, no. 1, pp. 144-152, 2002.

[118] T. R. Glare and M. O'callaghan, Bacillus Thuringiensis: Biology, Ecology and Safety, no. 632.951 G5, 2000.

[119] National Research Council, A. E. G. L. (NRCCAEGL), Acute Exposure Guideline Levels for Selected Airborne Chemicals, vol. 9, National Academies Press, 2009.

[120] A. M. Aboul-Enein, M. A. Aboul-Soud, H. K. Said et al., "Hepatoprotective effects of antioxidants against non-target toxicity of the bio-insecticide spinosad in rats," African Journal of Pharmacy and Pharmacology, vol. 6, no. 8, pp. 550-559, 2012.

[121] H. M. Nasr, F. M. El-Demerdash, and W. A. El-Nagar, "Neuro and renal toxicity induced by chlorpyrifos and abamectin in rats: Toxicity of insecticide mixture," Environmental Science and Pollution Research, vol. 23, no. 2, pp. 1852-1859, 2016.
[122] C. Liu, M. Li, Y. Cao et al., "Effects of avermectin on immune function and oxidative stress in the pigeon spleen," ChemicoBiological Interactions, vol. 210, no. 1, pp. 43-50, 2014.

[123] M. Hmani, H. Ben Saad, I. Ben Amara et al., "Toxicological Study and Oxidative Stress Evaluation for Safety Assessment of Bacillus thuringiensis Vip3Aa16 Toxin in Adult Mice," International Journal of Peptide Research and Therapeutics, vol. 23, no. 3, pp. 371-379, 2017.

[124] C. Hsu, B. Chi, M. Liu, J. Li, C. Chen, and R. Chen, "Phosphineinduced oxidative damage in rats: role of glutathione," Toxicology, vol. 179, no. 1-2, pp. 1-8, 2002.

[125] C.-H. Hsu, B.-C. Han, M.-Y. Liu, C.-Y. Yeh, and J. E. Casida, "Phosphine-induced oxidative damage in rats: Attenuation by melatonin," Free Radical Biology \& Medicine, vol. 28, no. 4, pp. 636-642, 2000.

[126] L. G. Costa, G. Giordano, M. Guizzetti, and A. Vitalone, "Neurotoxicity of pesticides: A brief review," Frontiers in Bioscience, vol. 13, no. 4, pp. 1240-1249, 2008.

[127] D. E. Ray, "Pesticides derived from plants and other organisms," in Handbook of Pesticide Toxicology, W. J. Hayes Jr. and E. R. Laws, Eds., vol. 2, pp. 585-636, Toronto: Academic Press, 1991.

[128] J. P. Leahey, "Metabolism and degradation," in The Pyrethroid Insecticides, J. P. Leahey, Ed., Taylor and Francis, Philadelphia, USA, 1985.

[129] P. G. Wislocki, L. S. Grosso, and R. A. Dybas, "Environmental aspects of abamectin use in crop protection," in Ivermectin And Abamectin, pp. 182-200, Springer, New York, NY, USA, 1989.

[130] CDPR, Abamectin: Risk Characterization Document (Revised, August 12, 1993). California Department of Pesticide Regulation, Medical Toxicology and Worker Health and Safety Branches, California Environmental Protection Agency, Sacramento, CA, USA, 1993.

[131] L. D. Wise, H. L. Allen, C.-M. L. Hoe, D. R. Verbeke, and R. J. Gerson, "Developmental neurotoxicity evaluation of the avermectin pesticide, emamectin benzoate, in Sprague-Dawley rats," Neurotoxicology and Teratology, vol. 19, no. 4, pp. 315-326, 1997.

[132] T. C. Marrs, Mammalian Toxicology of Insecticides, no. 12, Royal Society of Chemistry, 2012.

[133] U. S. E. P. A. (US EPA), Notice of Filing of Pesticide Petitions, Federal Register, 1999.

[134] M. J. Al-Azzawi, Z. S. Al-Hakkak, and B. W. Al-Adhami, "In vitro inhibitory effects of phosphine on human and mouse serum cholinesterase," Toxicological \& Environmental Chemistry, vol. 29, no. 1, pp. 53-56, 1990.

[135] W. T. Potter, V. F. Garry, J. T. Kelly, R. Tarone, J. Griffith, and R. L. Nelson, "Radiometric assay of red cell and plasma cholinesterase in pesticide appliers from minnesota," Toxicology and Applied Pharmacology, vol. 119, no. 1, pp. 150-155, 1993.

[136] E. R. N. 528/2012, Finalised in The Standing Committee on Biocidal Products at Its Meeting on 27 September 2013, concerning The Making Available on The Market And Use of Biocidal Products (Aluminium Phosphide), Germany, 2012.

[137] H. Kidd and D. R. James, The Agrochemicals Handbook, 1991.

[138] A. S. Al-Sarar, Y. Abobakr, A. E. Bayoumi, and H. I. Hussein, "Cytotoxic and genotoxic effects of abamectin, chlorfenapyr, and imidacloprid on CHOK1 cells," Environmental Science and Pollution Research, vol. 22, no. 21, pp. 17041-17052, 2015.

[139] USEPA, Spinosad Pesticide Fact Sheet No. HJ 501C, Office of Pesticides and Toxic Substances, 1997. 
[140] U. S. E. P. A. (US APE), Pesticide Fact Sheet Number 7803-51-2, Phosphine, Office of Pesticides and Toxic Substances (7505C), Washington, DC, USA, 1999.

[141] A. D. Kligerman, J. B. Bishop, G. L. Erexson et al., "cytogenetic and germ cell effects of phosphine inhalation by rodents: II. subacute exposures to rats and mice," Environmental and Molecular Mutagenesis, vol. 24, no. 4, pp. 301-306, 1994.

[142] M. Moriya, T. Ohta, K. Watanabe, T. Miyazawa, K. Kato, and Y. Shirasu, "Further mutagenicity studies on pesticides in bacterial reversion assay systems," Mutation Research - Genetic Toxicology and Environmental Mutagenesis, vol. 116, no. 3-4, pp. 185-216, 1983.

[143] S. M. Ensley, "Pyrethrins and pyrethroids," in Veterinary Toxicology, pp. 591-595, 2nd edition, 2012.

[144] M. F. Ismail and H. M. Mohamed, "Deltamethrin-induced genotoxicity and testicular injury in rats: Comparison with biopesticide," Food and Chemical Toxicology, vol. 50, no. 10, pp. 3421-3425, 2012.

[145] H. Fetoui, A. Feki, G. B. Salah, H. Kamoun, F. Fakhfakh, and R. Gdoura, "Exposure to lambda-cyhalothrin, a synthetic pyrethroid, increases reactive oxygen species production and induces genotoxicity in rat peripheral blood," Toxicology \& Industrial Health, vol. 31, no. 5, pp. 433-441, 2015.

[146] P. K. Khan and K. S. Awasthy, "Cytogenetic toxicity of neem," Food and Chemical Toxicology, vol. 41, no. 10, pp. 1325-1328, 2003.

[147] K. S. Awasthy, O. P. Chaurasia, and S. P. Sinha, "Genotoxic Effects of Crude Extract of Neem (Azadirachta Indica) in Bone Marrow Cells of Mice," Cytologia, vol. 60, no. 2, pp. 189-193, 1995.

[148] U. S. E. P. A. (US EPA), Office of Prevention Pesticides And Toxic Substances, Carcinogenicity Peer Review of Pyrethrins, Washington, DC., USA, 1995. 

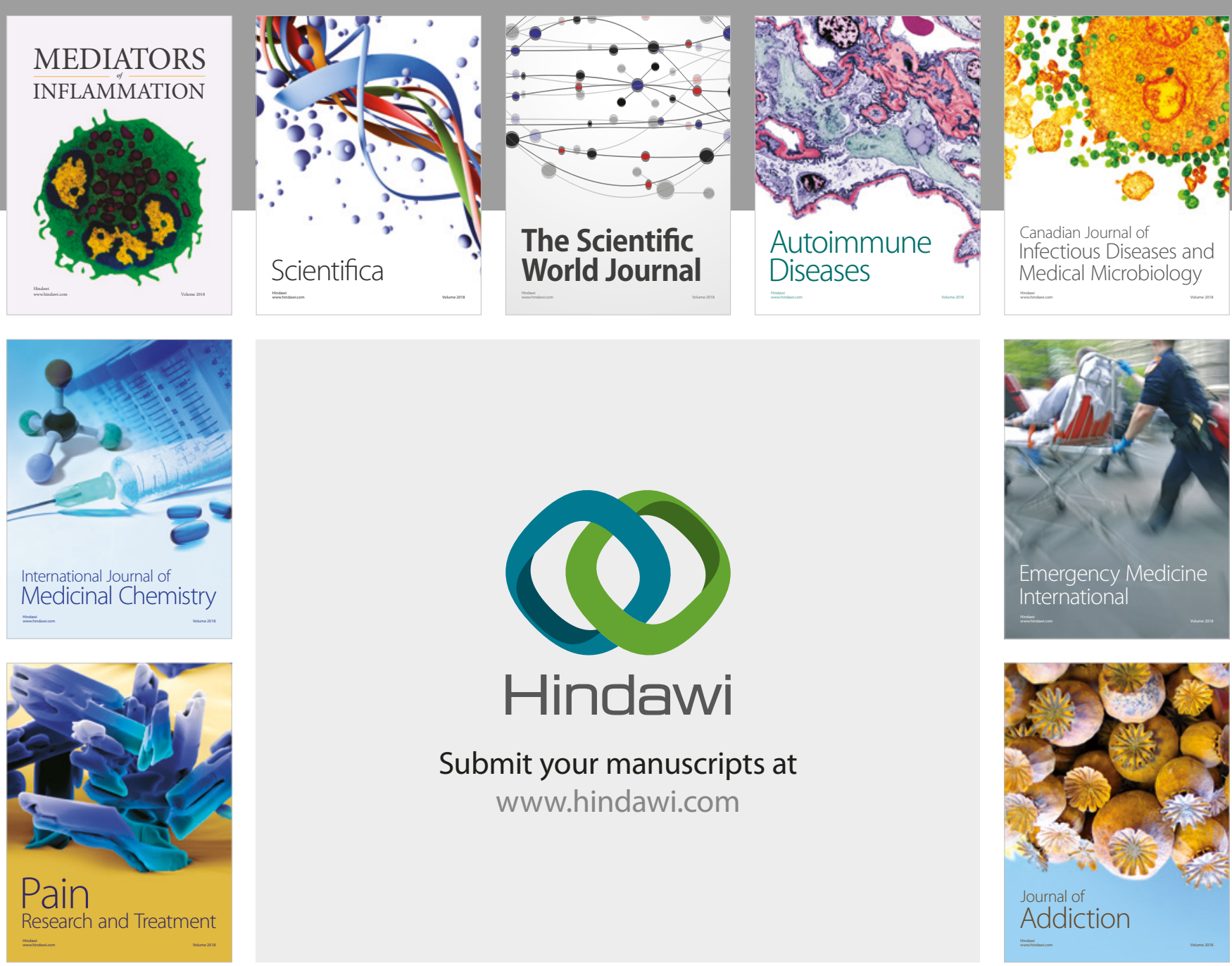

Canadian Journal of
Infectious Diseases and Medical Microbiology

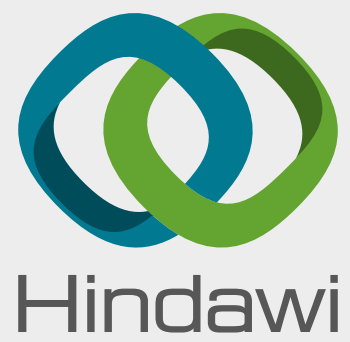

Submit your manuscripts at

www.hindawi.com
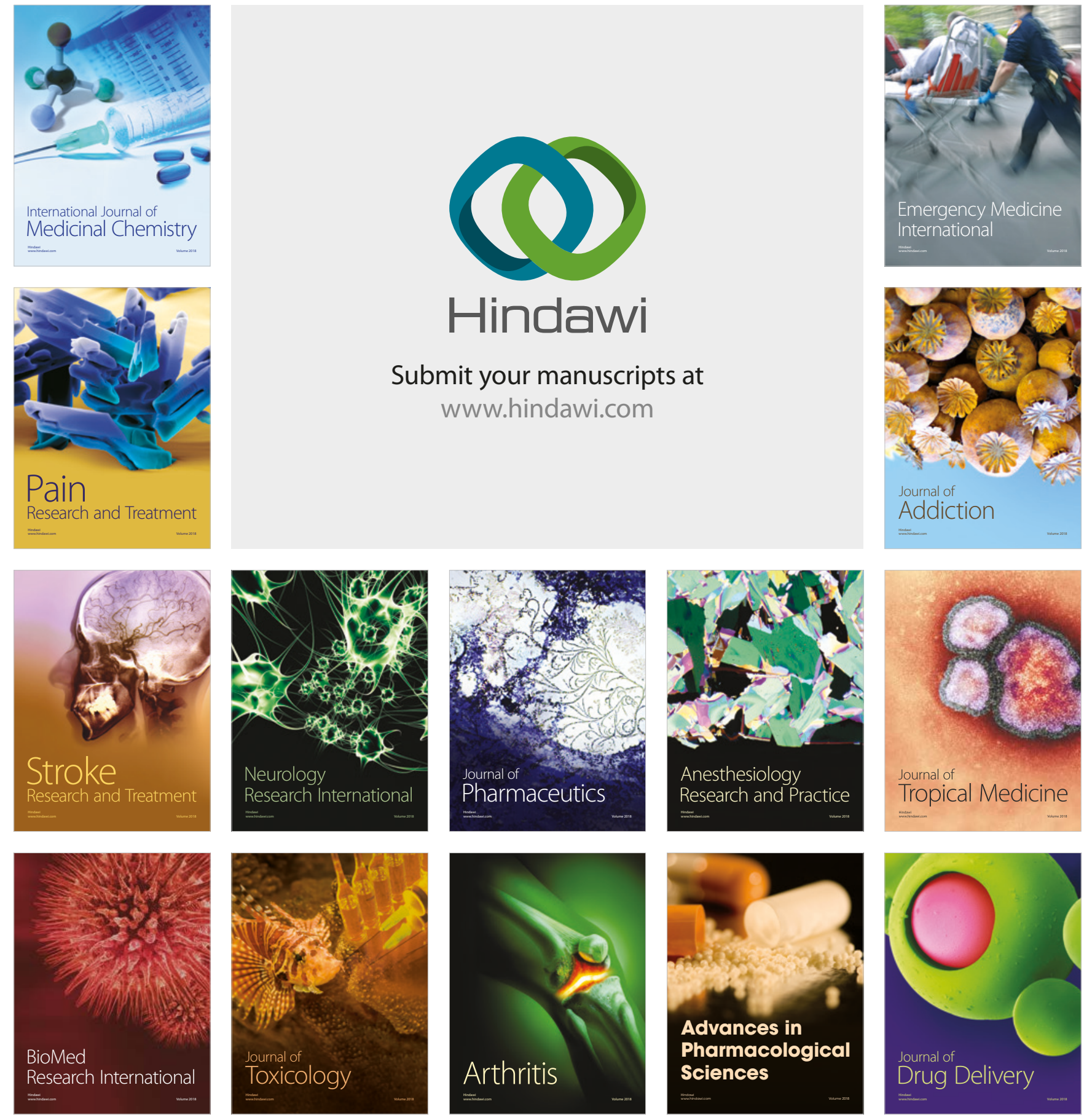